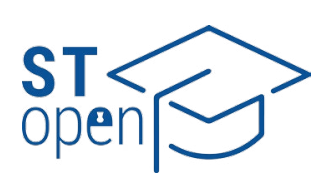

(C) 2021 The Author(s)

ST-OPEN @ 2021

\title{
Sacral architecture of Split parish churches built since 1990
}

\section{Gabrijela Matić (D), Željko Peković}

Art History Department, Faculty of Humanities and Social Sciences,

University of Split, Split, Croatia
Correspondence to:

Gabrijela Matić

Faculty of Humanities and Social Sciences,

Poljička cesta 35, 21000 Split, Croatia

matic.gabrijela@gmail.com
Objective: The article aims to provide a typology of contemporary sacral architecture in Croatia by analyzing the churches built in the Split area after the post-World War II ban on building churches was abolished.

Methods: Parish archives and the Archive of Split-Makarska Archdiocese provided documentation that allowed for an in-depth analysis of newly built churches. A short historical overview is provided to corroborate the need of respective parishes for a new church; this is followed by an analysis of the ground plan and other architectural features. The church architecture is considered in the light of post-Council instructions that affect the appearance of contemporary churches. Finally, we provide an analysis of the relationship between sacral buildings and their urban environment.

Results: Twelve new parish churches were built in the city of Split City area since 1990. A data analysis revealed that the major problem during church construction projects was the visual integration of the churches into the Split neighborhoods. The shape and size of the buildings was partly dictated by the urban environment. Most churches are located in the immediate vicinity of the center of the neighborhood. The churches mainly differed by the shape of their bell towers, which were used by the architects to convey their devotion to or departure from tradition. The move toward central-plan buildings, which would be expected in the light of post-Council guidelines, did not emerge in Split.

Conclusion: A comparison of contemporary sacral architecture in Split did not reveal a defined church design typology. The contemporary sacral architecture in Split has not completely turned to new trends and is still partly trying to keep the tradition, as reflected in the ground plan and bell tower design. Architects have abandoned the strong longitudinal axis and have been dimensioning the churches based on the real needs.

\section{Introduction}

Contemporary sacral architecture does not adhere to any preconceived models; it is free of the canon and poses a real challenge for architects. The Second Vatican Council only 
set certain guidelines, proposing that sacral architecture be considered through the lens of its liturgical function (Second Vatican Council, 2008). Transforming a church into a contemporary, dignified, functional, and consecrated space requires an interdisciplinary approach and close cooperation between experts in the fields of liturgy, architecture, civil engineering, art history and the Archbishop's Office. This freedom of sacral design provides architects with a choice to either lean on tradition or do away with it entirely.

According to Lewis Mumford (1968), beyond a place of prayer, the church has historically always been the center stage of day-to-day social life, as well as a museum of Christian art. This paper explores the present-day status of the church, its artistic value, its relationship with tradition, as well as its urban environment, based on the example of the city of Split (Figure 1). Following the independence of the Republic of Croatia and the introduction of democracy in the early 1990s (Perković Paloš, 2020), Split found itself in a predicament where the Archdiocese needed to act urgently and provide the eastern part of the city with adequate and dignified conditions for worship. The eastern part of the city was built during the former socialist regime, which entertained no plans for the construction of sacral buildings. In the wake of the illegal and uncontrolled construction that ensued, it was difficult to source satisfactory and available sites in the eastern parts of the city (Klempić, 2004).

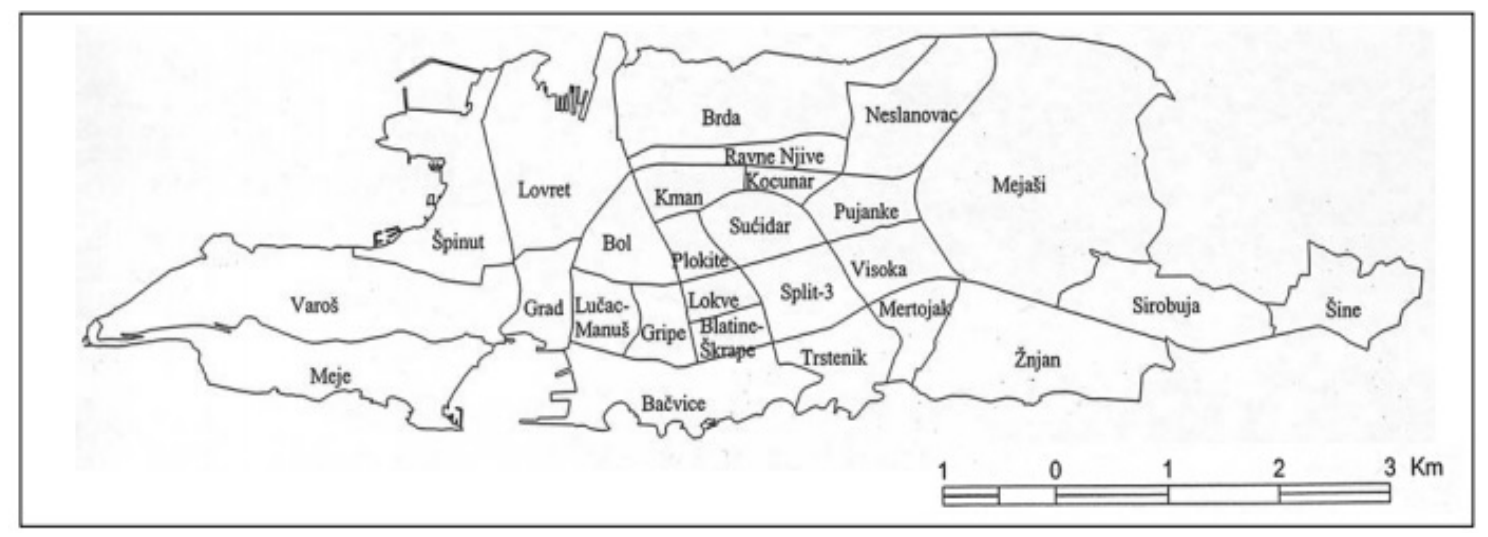

Figure 1. Split city plan. The eastern portion of the city (Sućidar, Kocunar, Ravne Njive, Brda, Neslanovac, Pujanke, Visoka, Trstenik, Mertojak, Mejaši, Žnjan, Sirobuja districts) was built during the erstwhile socialist regime, which made no plans to build sacral buildings (Klempić, 2004, reproduced with permission).

In 1993, the Interdisciplinary and Multidisciplinary Research Center at the University of Split (CIMIS) made an analytical "Survey of priority sites for Catholic churches in the Split city area, from the perspective of rational civil engineering and adding new community facilities". The study was commissioned by the Archdiocese and Split city government with the aim of pinpointing 12 sites suitable for new parish churches. The study provided answers to most of the questions raised by contemporary sacral architecture. After analyzing the on-the-ground situation, its authors emphasized that sacral architecture should be integrated into, but not blended with its urban environment. Based on the analysis of the 1991 census of the eastern parts of Split, they concluded that the optimal church area would be up to $400 \mathrm{~m}^{2}$ (Tušek, 1996). 
Later, in 1995, the Croatian Institute of Pastoral Liturgy held a conference for church managers, architects and artists in Split. Various experts presented their ideas and guidelines regarding contemporary sacral architecture and approached this issue using interdisciplinary methods. The guidelines for contemporary sacral buildings, as compiled in the Proceeding, emphasized the importance of post-conciliar instructions in shaping the sacral space, such as the principle of moving away from strong longitudinal floor plans (Škunca, 1996). More specifically, the post-conciliar liturgical reform posed that Christ is the Head and the Church the mystical Body, which performs liturgy in communion with Christ. The turn in the typology of the floor plan in contemporary sacral buildings thus stems from the liturgical reform of the Second Vatican Council; The Council emphasized that the liturgy should be the backbone of church design, in order to encourage active participation of the faithful (Second Vatican Council, 2008).

\section{Sacral architecture of Split since 1990}

Figure 2 shows the sites of 12 parish churches built in the City of Split since 1990. A separate analysis of each church is presented below.

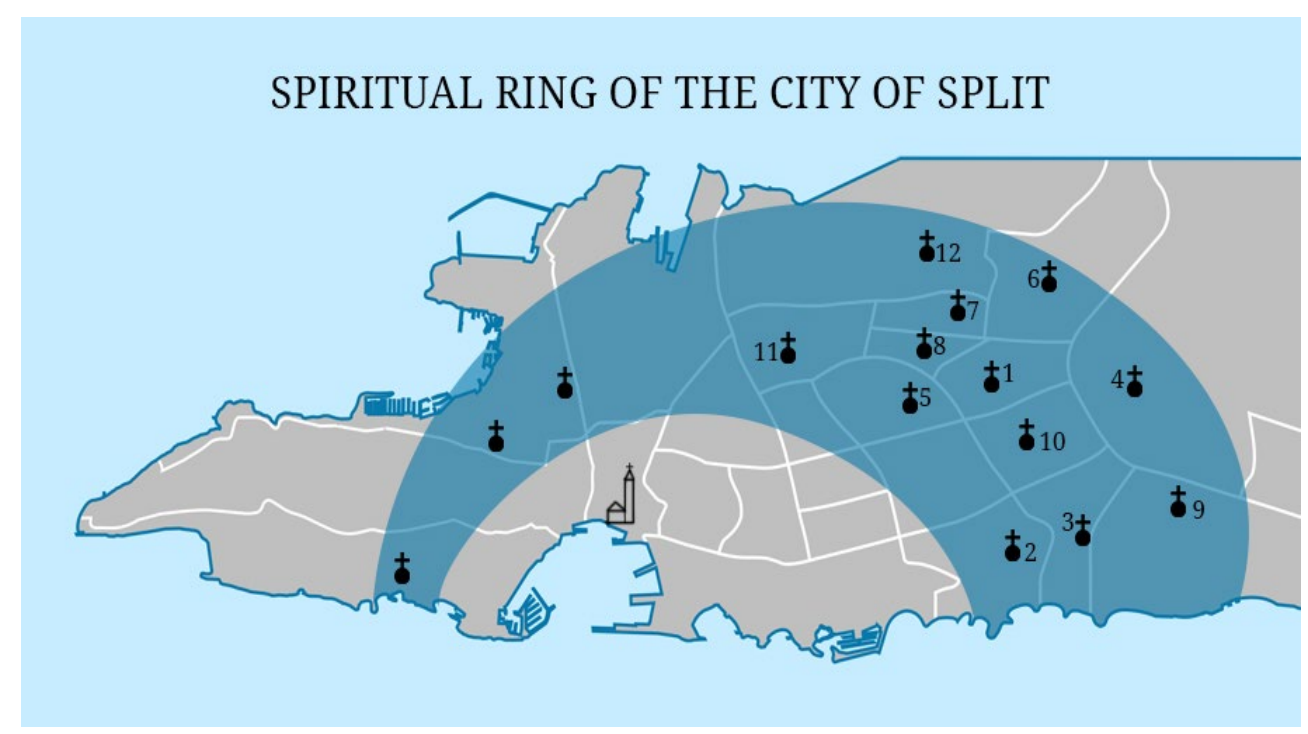

Figure 2. The sites of 12 new parish churches built in the city of Split since 1990. 1 - Church of St. Paul the Apostle in Pujanke; 2 - St. Joseph's Church in Mertojak; 3 - Church of Our Lady of Mercy in Žnjan; 4 - St. Liborius' Church in Mejaši; 5 - Church of St. John the Baptist in Trstenik; 6 - St. Mark's Church in Neslanovac; 7 - Church of St. Matthew the Apostle in Ravne Njive; 8 - Church of St. Luke the Evangelist in Kocunar; 9 - Church of St. Leopold Bogdan Mandić in Sirobuja; 10 - Church of the Sacred Heart of Jesus in Visoka; 11 - Church of St. Andrew the Apostle in Sućidar; 12 - Church of the Motherhood of the Blessed Virgin Mary in Brda (Source: author's drawing).

\section{Church of St. Paul the Apostle in Pujanke}

St. Paul's Parish in Pujanke was founded in 1980. Prior to the construction of the new church, the parishioners used to be distributed across the neighboring Visoka and Kman Parishes (Vidović, 2004). Construction of the new church (Figure 3) began in 1996, based on drawings by architects Ante Lijić and Tihomir Liović (Vilogorac, 2005). St. Paul the Apostle in Pujanke was the first church built in Split after the Homeland War (Perković Paloš, 2020), during a time when the spirit of the people was united and directed toward 
restoring the Croatian identity, which was deeply reflected in the fact that the church's location and size - it took over a large chunk of available space in the neighborhood - was uncontested at the time. The church was barely mentioned in the daily press, which goes to show that, unlike the later churches, its construction was unproblematic and received no public backlash.

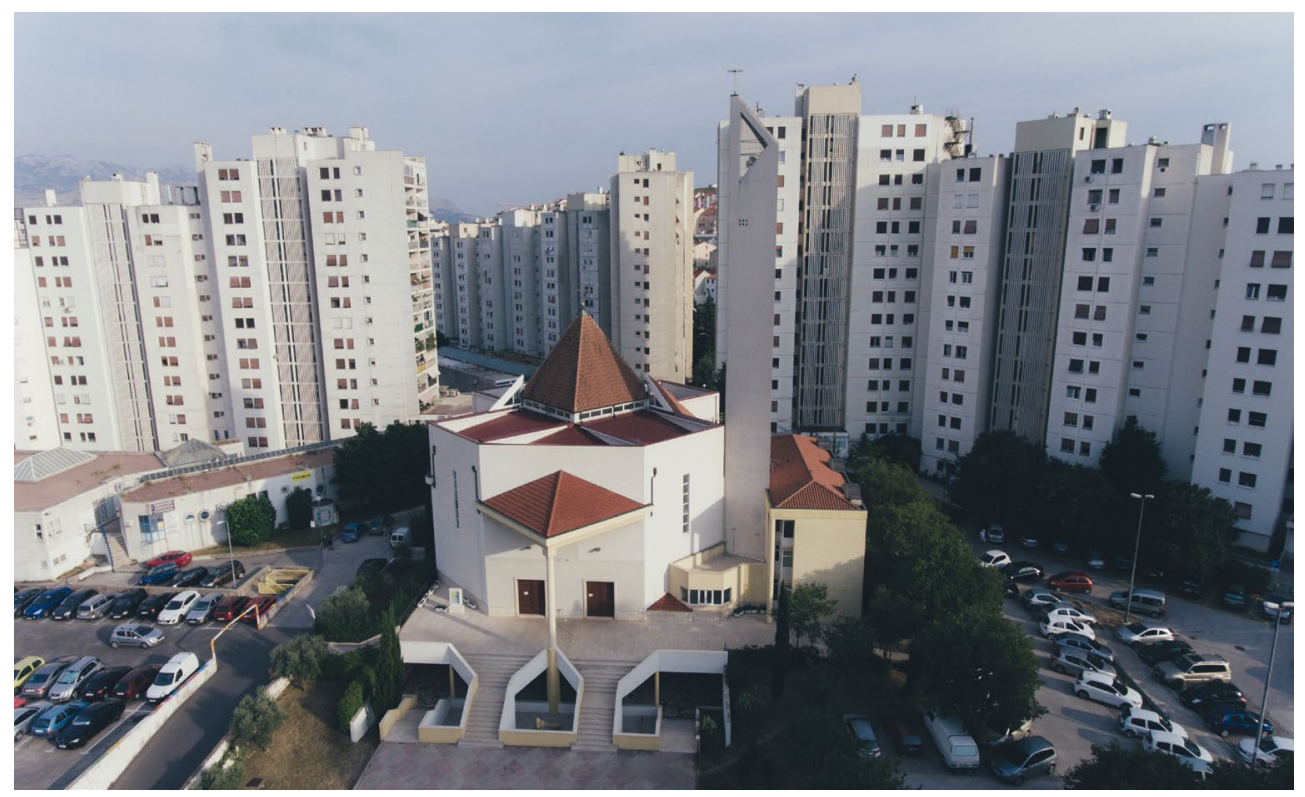

Figure 3. The Church of St. Paul the Apostle in Pujanke. Aerial view of the front façade and pastoral center (Source: author's own archive).

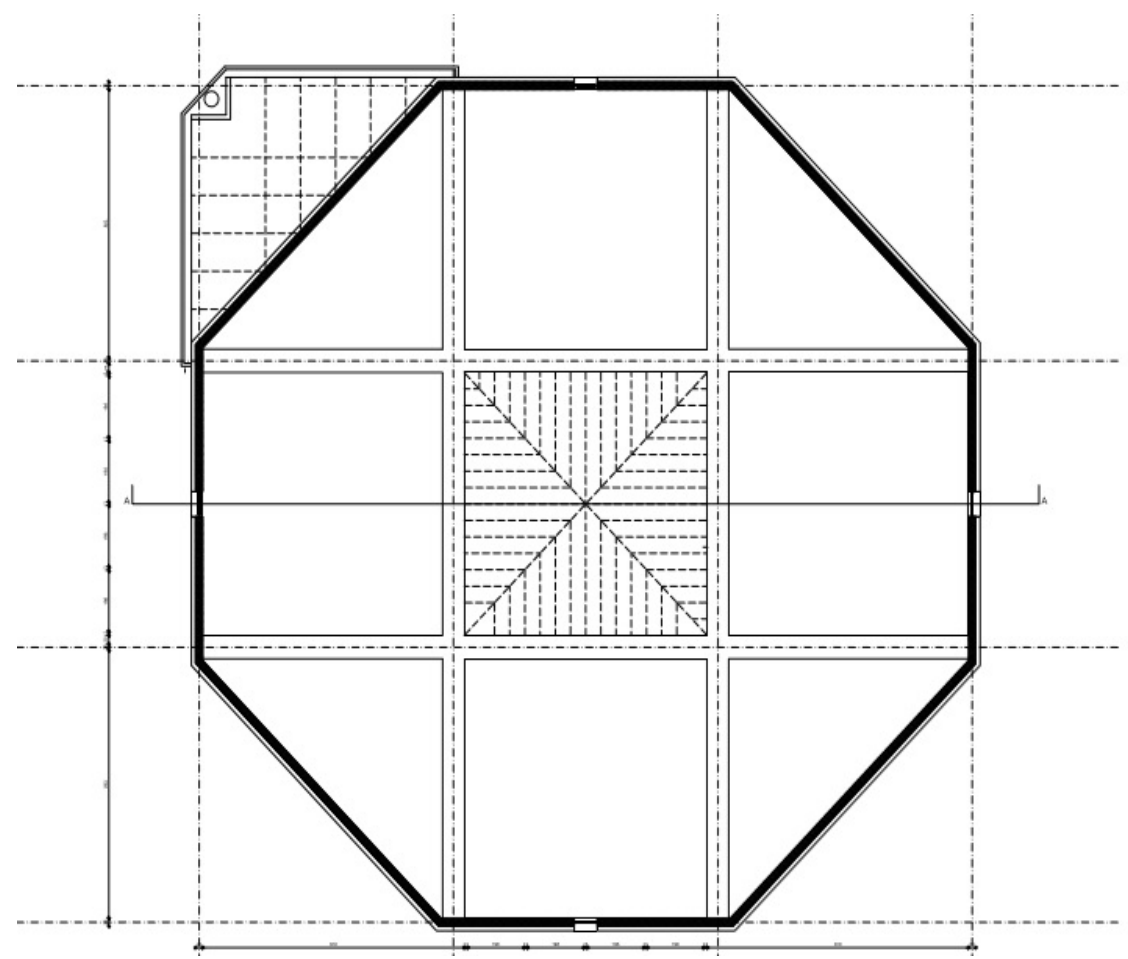

Figure 4. The floor plan of the Church of St. Paul the Apostle in Pujanke. The church is a centrally planned Greek-crossin-octagon (Split-Makarska Archdiocese Archives, reproduced with permission). 
St. Paul the Apostle has a central plan (Figure 4). It is a Greek-cross-in-octagon plan with a central pitched roof. Together with the pastoral center, the church covers $1,100 \mathrm{~m}^{2}$. The church façade features two doors with a gable roof. A slender pillar extending from the middle of the porch to the axis of the roof is a recognizable feature of the façade. The church sits on an elevated plateau, above double flight steps. There is a square in front of the church. An equilateral-triangle-plan bell tower leans against the church wall. The slender bell tower features a slanted end and equilateral triangle openings on two sides. It terminates in a thin cross and has no actual bells. Just inside the church entrance, there is a vestibule or narthex. Inside, two pillars support the choir, which sits on top of the entryway. The white and yellow shades of the façade are also used in the interior. The church ceiling is markedly yellow and cruciform, with coffered arms. The white center of the ceiling, also the center of the Greek cross, is quadrilateral and extends to the apex of the roof. The chancel rises three steps above the nave, terminates in a flat end, and features a stone ambon (a liturgical platform in the chancel from which biblical texts are read), altar, and tabernacle. The pastoral center stands next to the church; however, its yellow façade diverts attention away from the church and violates the cohesiveness of the entire building.

\section{St. Joseph's Church in Mertojak}

St. Joseph's Parish in Mertojak was founded in 1991 by merging a part of the Parish of the Heart of Jesus in Visoka and the Parish of Our Lady of Mercy in Žnjan (see Figure 2). Before its building, liturgy used to be performed in a $150 \mathrm{~m}^{2}$ fallout shelter belonging to a kindergarten (Vidović, 2004). Construction of the new St. Joseph's Church began in 1996, on top of the shelter (Figure 5), based on the design of architects Neno Kezić and Eugen Širola (Vilogorac, 2005).

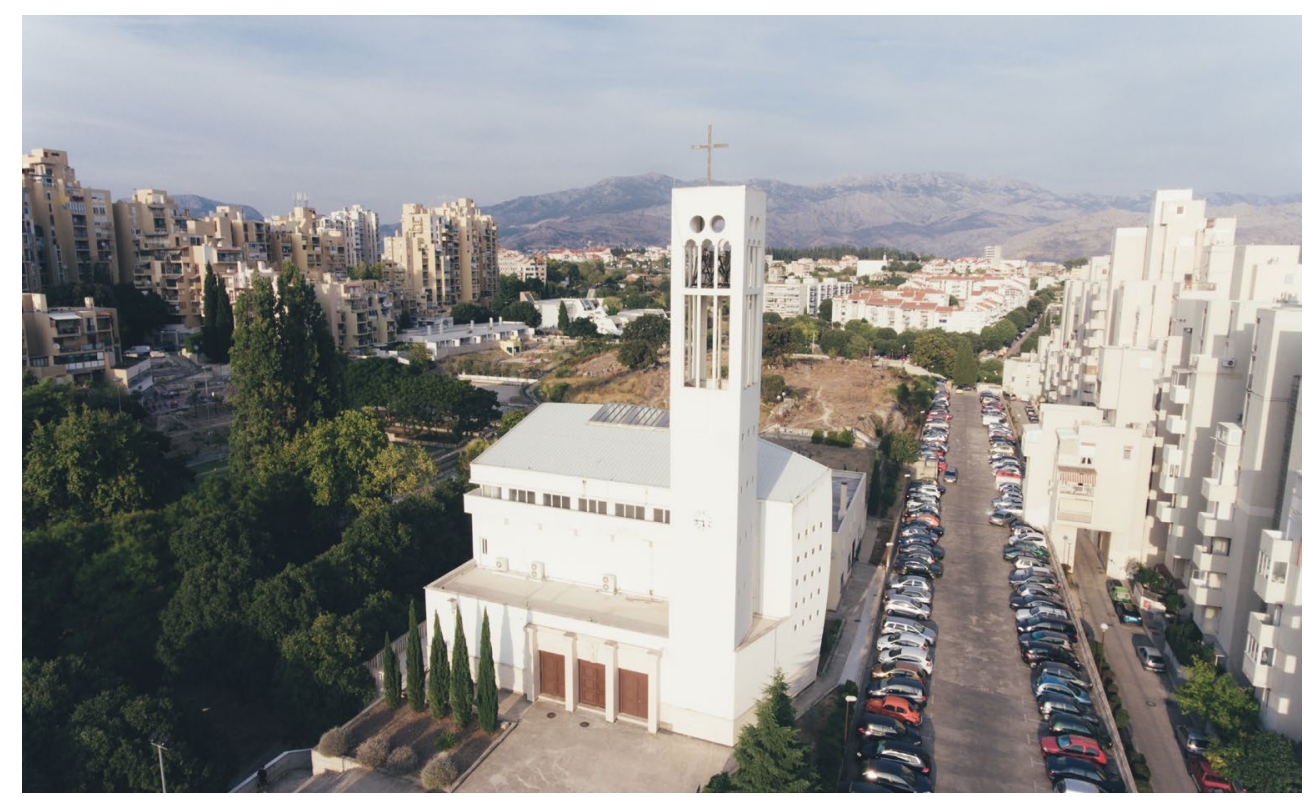

Figure 5. St. Joseph's Church. Aerial view of the front façade; the pastoral center lies behind the church (Source: author's own archive). 


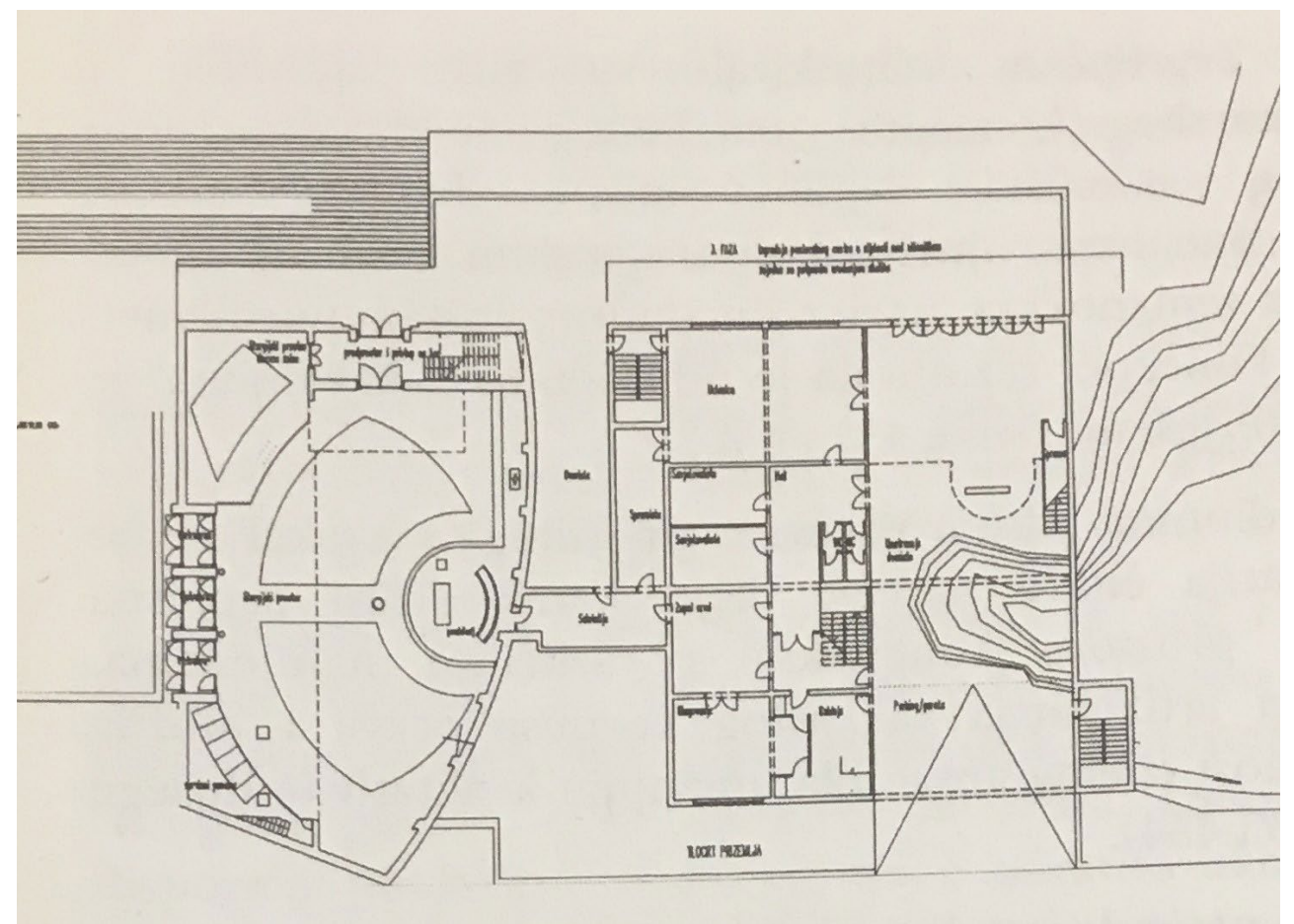

Figure 6. The floor plan of St. Joseph's Church with its pastoral center. The church plan is irregular, with a markedly curved wall of the chancel (Tušek, 1996, p. 438, reproduced with permission).

The floor plan (Figure 6) is irregular. It resembles an ark due to the curved eastern wall of the chancel. The west and north façades are solid, but the south one is recessed. The church has an area of $400 \mathrm{~m}^{2}$ (Tušek, 1996). A bell tower with two bells is adjacent to the church; unlike the contemporary church plan, the bell tower is modeled on traditional Dalmatian bell towers. The bell tower features a clock in the middle, three-mullioned windows, and circular openings at the top. The frame of the church's three front doors is made of marble; above the middle door, there are decorative strips featuring the Croatian wattle and a cross with the same pattern. The four pilasters that separate the wooden doors are also made of marble. The church does not have a strong longitudinal axis, and its chancel is somewhat cramped. It houses a stone altar, ambon, and tabernacle. The curved east wall behind the chancel is coffered with square panels. The portion of the east wall set directly behind the chancel features a drawing of a purple cross. The pastoral center lies behind the church and does not detract from the façade aesthetic. Tušek (1996) described the church as an example of the "sovereignty in composing the imposing plasticity of the rounded volumes, following the footsteps of the best traditions of Croatian sacral architecture” by architects Kezić and Širola (Tušek, 1996, p. 435). Their reliance on tradition is apparent from the shape of the bell tower and the use of the typical Croatian wattle on the façade, but its irregular floor plan, which abandoned the strong longitudinal axis in the wake of post-conciliar instructions, is contemporary St. Joseph's Church in Mertojak poses the question of the degree to which tradition should be upheld in contemporary sacral architecture, without looking incompatible, contradictory, or forced. The answers to these questions should have been sought before the launch of the new wave of contemporary sacral building; however, due to the political situation and long stagnation in civil engineering, contemporary sacral architecture in Croatia did not have time to wait for systematic analyses. 


\section{Church of Our Lady of Mercy in Žnjan}

The parish was founded in 1966, also encompassing the St. Lawrence's Church, whose foundations date back to the 9th or 10th century. As that small, $28 \mathrm{~m}^{2}$ church was insufficient for a dignified worship, the Archdiocese originally set up a prefabricated aluminum structure to the north of the church as a temporary solution (Vidović, 2004). Construction of the new Parish Church of Our Lady of Mercy in Žnjan began in 1996, based on the design by Marijan Hržić (Vilogorac, 2005) (Figure 7).

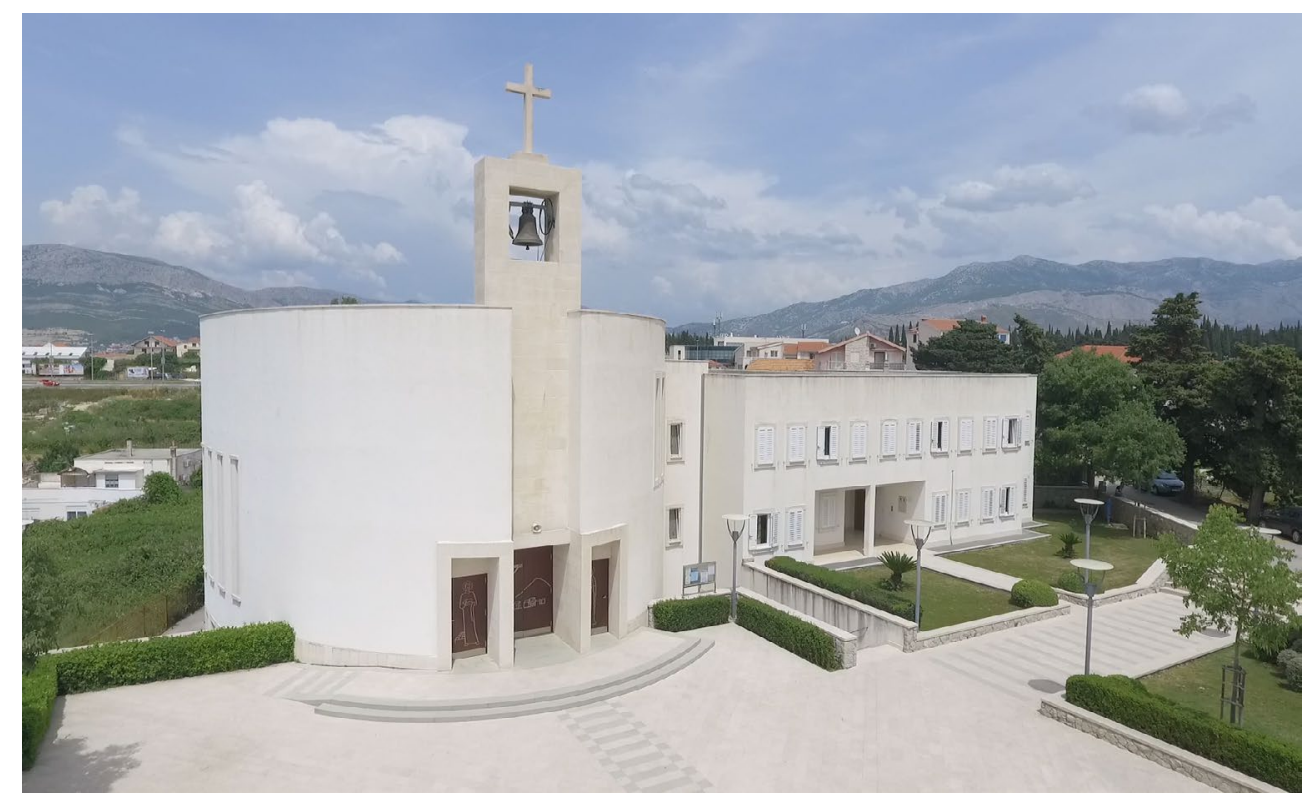

Figure 7. Church of Our Lady of Mercy in Žnjan. Aerial view of the front façade and pastoral center (Source: author's own archive).

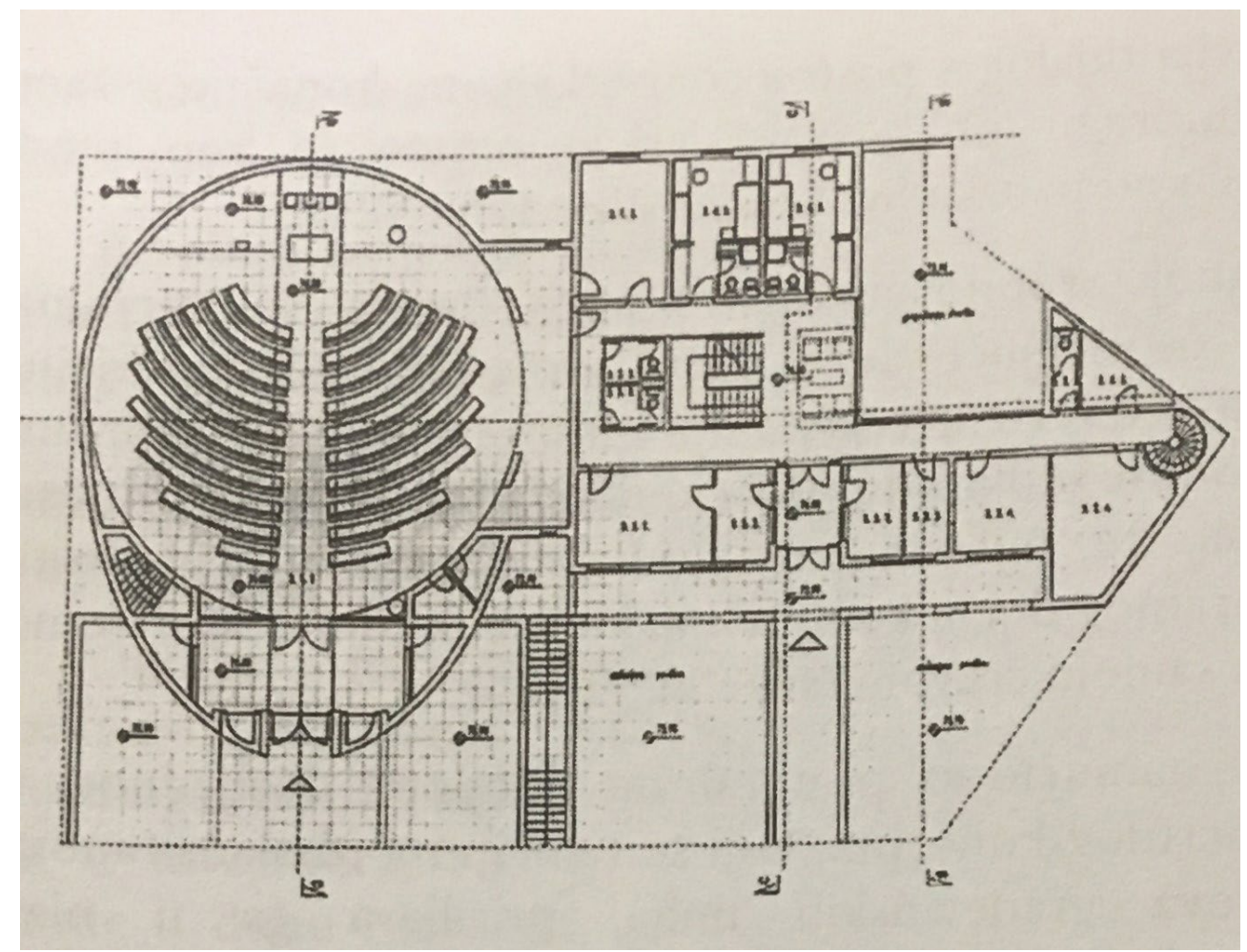

Figure 8. The floor plan of the Church of Our Lady of Mercy in Žnjan and the pastoral center. The church has a rounded elliptical plan (Tušek, 1996, p. 432, reproduced with permission). 
The Church of Our Lady of Mercy has a rounded elliptical floor plan (Figure 8). The façade is crowned with a bell gable, which is a traditional feature of the Eastern Adriatic coast architecture. In his analysis of bell towers in Split, Duplančić concluded that bell gables make up the majority and are the most durable type of bell tower in Split; the first was built next to St. Nicholas' Church in Marjan, in 1219 (Duplančić, 2011). The Parish Church of Our Lady of Mercy takes up an area of about $400 \mathrm{~m}^{2}$; its $850 \mathrm{~m}^{2}$ pastoral center lies to the east (Vlaić, 2011). The church entryway rises two steps above the church square with a stone fountain. Just behind the church entrance, there is a narthex, walled off from the rest of the church with PVC openings; to the right, there is a chapel, and to the left, there are stairs leading to the choir above the narthex, which follows the curvature of the church to its right half. The church pews follow the twist and turn of its floor plan. The chancel rises three steps above the rest of the church and terminates in a semicircle; the ambon, altar, and sedilia (seats in the chancel) are made of stone. To the right of the chancel, there is a baptismal font and a sacristy. The ceiling is coffered to resemble a sunken cross, and the roof windows feature the depictions of the twelve apostles. The Stations of the Cross, stained glass windows, and a mosaic behind the altar were painted by the academic painter Josip Botteri Dini. The church plan is in keeping with the post-conciliar recommendations on abandoning the strong longitudinal axis. The architect breathed a touch of tradition into the contemporary design by adding a bell gable. Unlike the rest of the church, this is made of stone, which is a traditional building material. The church surroundings are tranquil, without any high-rises. The church does not give the impression of having taken over the last available piece of open space in the neighborhood. More precisely, the part of Žnjan where the church was built has begun expanding only subsequently, giving the Church of Our Lady of Mercy the air of a peaceful oasis some distance away from the chaotic urban sprawl of Žnjan 2 (see Figure 2).

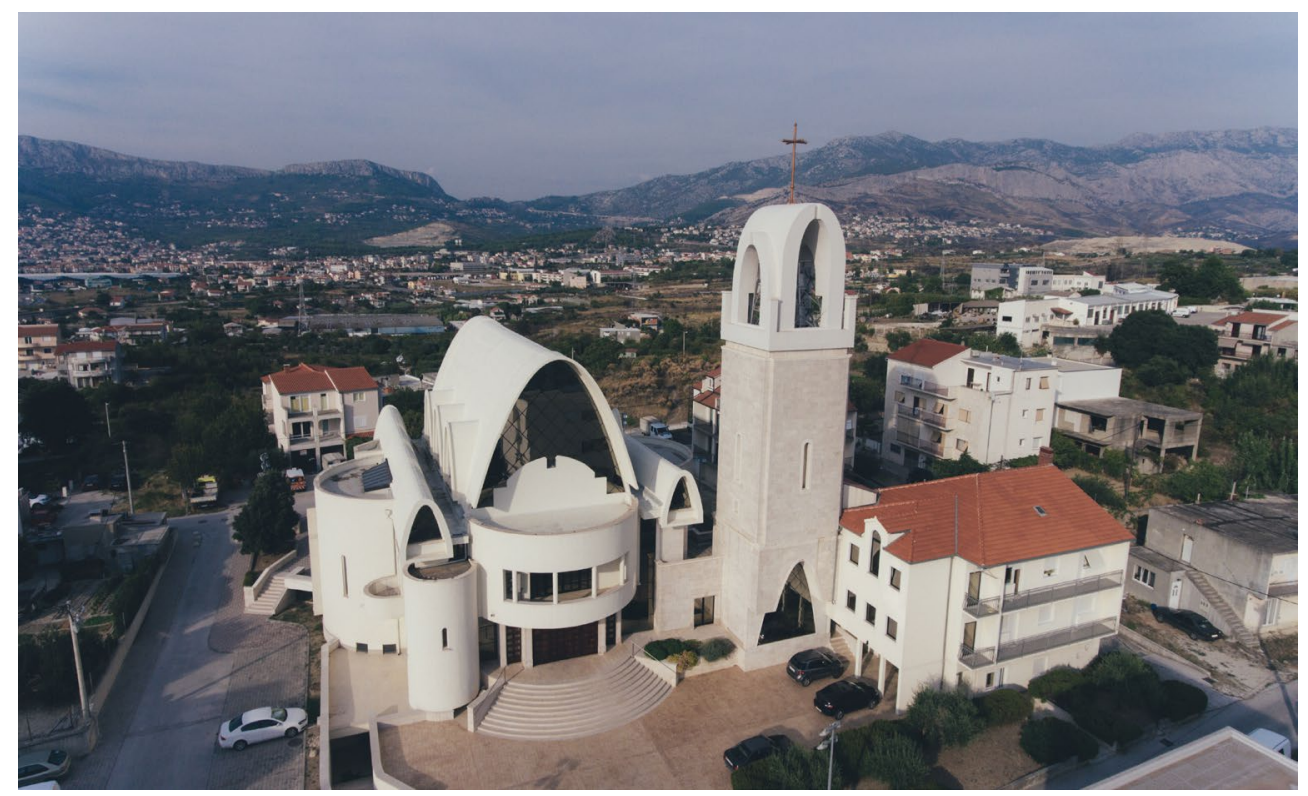

Figure 9. Aerial view of the front façade of St. Liborius' Church in Mejaši. The pastoral center is separated from the church proper (Source: author's archive). 


\section{St. Liborius' Church in Mejaši}

The parish was founded in 1975. It originally had no sacred building, as it was a new settlement in the eastern part of the city (see Figure 2). At first, a family building with a chapel on the first floor and a parish house on the second was erected as a makeshift solution. Construction of the St. Liborius' Church in Mejaši began in 1994, based on a drawing by the architect Slaven Rožić (Split-Makarska Archdiocese, 2016a) (Figure 9).

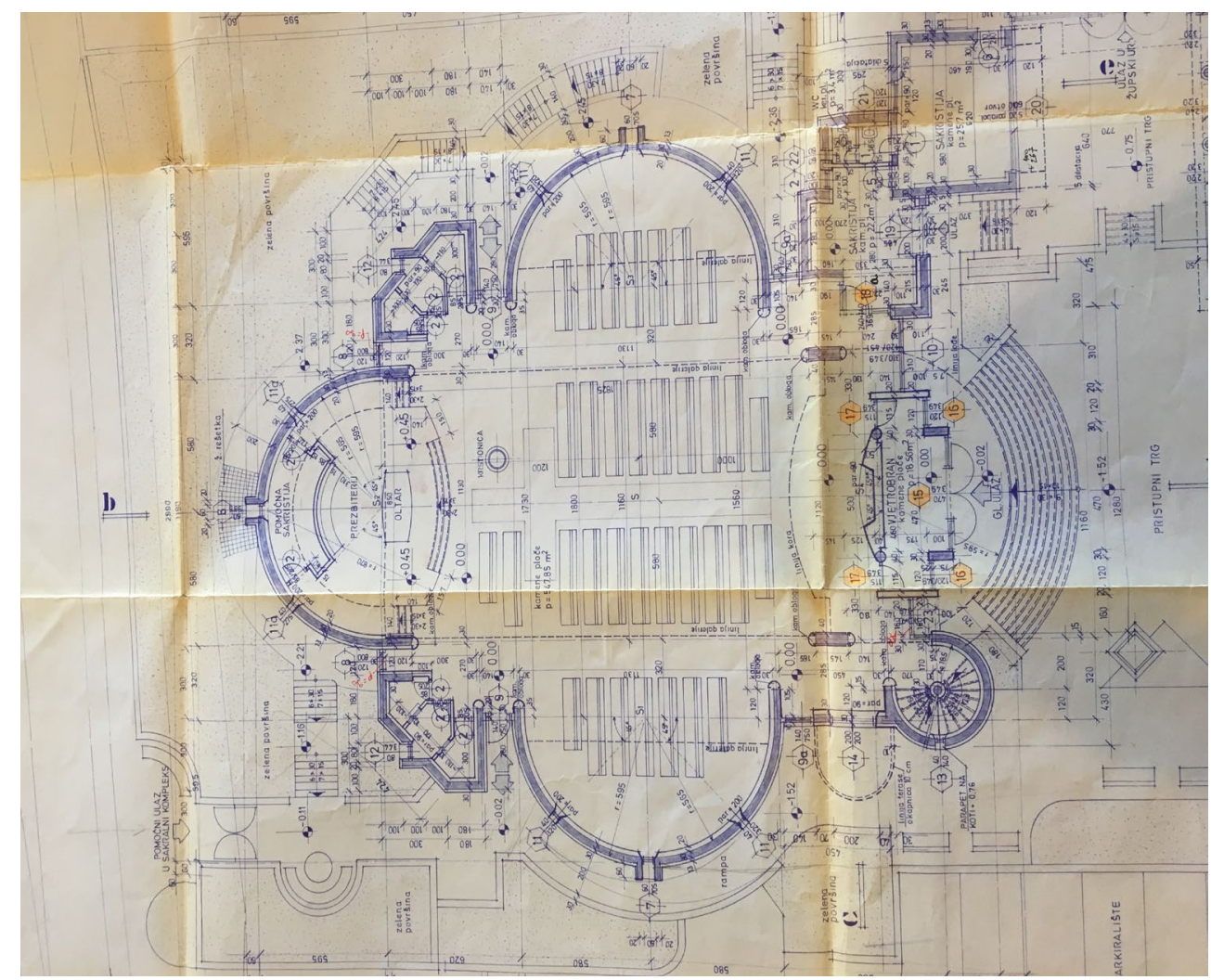

Figure 10. The floor plan of St. Liborius' Church in Mejaši. The cruciform floor plan is reminiscent of early Christian basilicas (St. Liborius' Parish Archive, reproduced with permission).

St. Liborius' Church has a cruciform plan reminiscent of early Christian basilicas, it has quatrefoil floor plan, with the area of $700 \mathrm{~m}^{2}$ (Vidović, 2004) (Figure 10). Unlike other churches erected in the Split area since 1990, St. Liborius' Church stands out with its monumental size. The church had been designed long before the Interdisciplinary and Multidisciplinary Research Center at the University of Split issued its building guidelines for the Spiritual Ring in Split, which finally set $400 \mathrm{~m}^{2}$ as the optimal size of new sacral buildings (Tušek, 1996). The design was originally intended for a church in Brda, as a large number of the faithful gravitated toward that area. However, that parish was split into three smaller ones by a decision of the Archbishop's Ordinariate, removing the need for such a large church. The Mejaši parish priest recognized the potential of the design and adopted it with minor modifications to build St. Liborius' Church. Pastor dn Anđelko Dukić praised the church for preserving the connection with tradition, unlike other new contemporary churches, and cited the Holy Trinity Church in Poljud as its early-Christian model (Dukić, personal communication, August 10, 2018). However, some might claim that the church is more reminiscent of Islamic architecture due to its parabolic arches. This 
type of arch is visible on the church façade, above the entryway, and on the side galleries, always inlaid with glass. The pattern is repeated in the lower zone of the bell tower and connects the façade and the bell tower into a stylistic whole. Steps lead from the large church square to its entryway, which is overhung by the rounded volume of the choir, giving the flat façade an additional dimension. The chancel is elevated and has an apsidal ending. Church pews are placed in the side apses, and the main nave is flanked by galleries with semicircular arcades. The grandeur of the church in Mejaši is justified by the fact that, after St. Peter's Co-cathedral in Gripe, it was supposed to be the next big church on the outskirts of the city and attract the newcomers to the city.

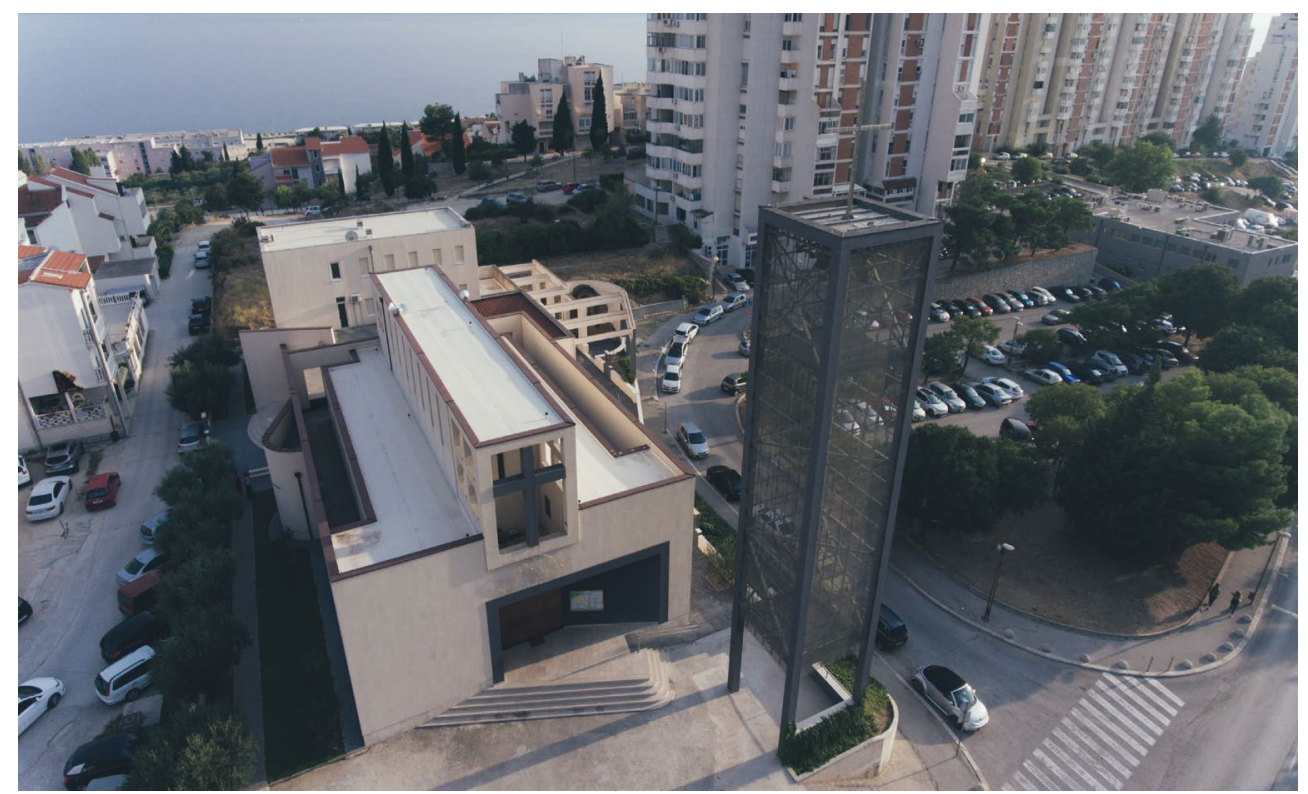

Figure 11. The façade of the Church of St. John the Baptist in Trstenik. The pastoral center lies beyond the church (Source: author's archive).

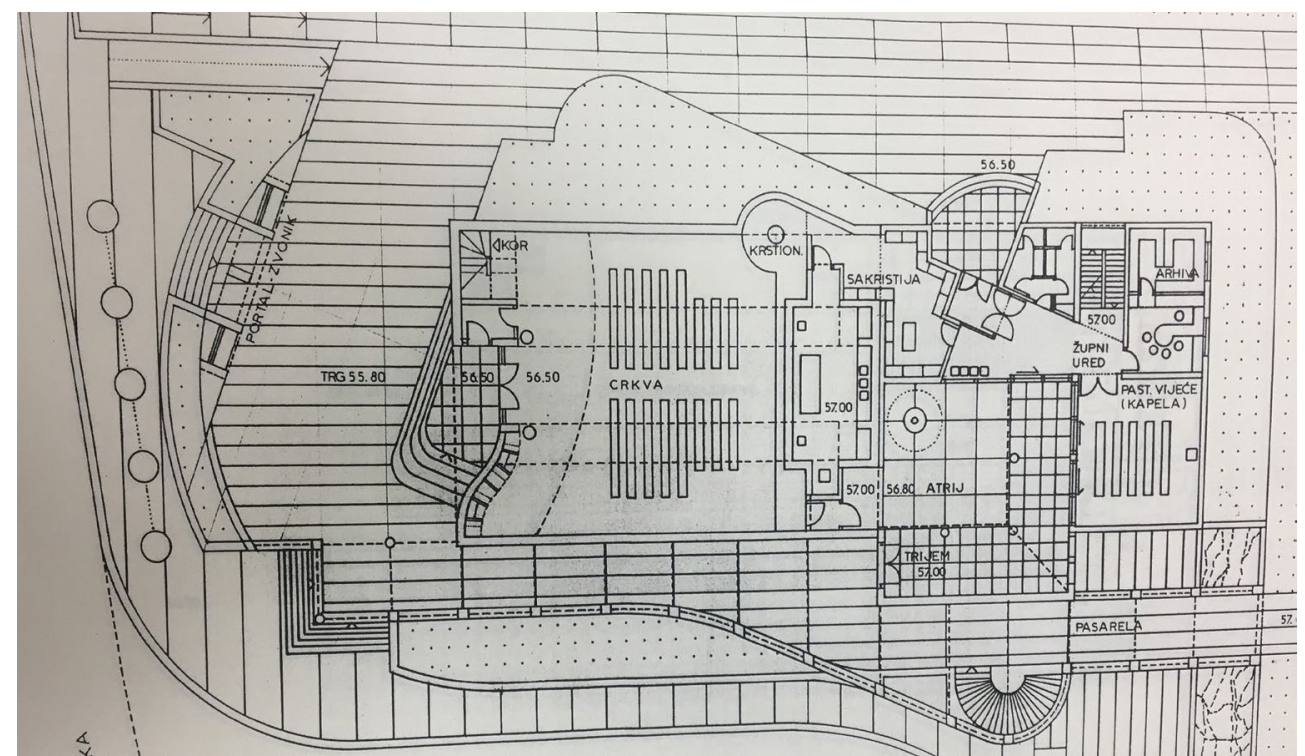

Figure 12. The floor plan of the Church of St. John the Baptist in Trstenik. The $380 \mathrm{~m}^{2}$ rectangular-plan church is one of the smaller churches built in Split after 1990 (Split-Makarska Archdiocese Archive, reproduced with permission). 


\section{Parish of St. John the Baptist in Trstenik}

The Parish of St. John the Baptist in Trstenik was founded in 1991. As the new parish had no churches, the Territorial Community provided an old elementary school building as a temporary place of worship (Vidović, 2004). Construction of the Church of St. John the Baptist in Trstenik began in 1996, based on the drawings by architects Jerko Rošin and Robert Plejić (Vilogorac, 2005) (Figure 11).

St. John the Baptist is a single-nave rectangular-plan church (Figure 12). The church covers $380 \mathrm{~m}^{2}$ (Vidović, 2004). It has a designated square in the front, with steps leading to its screened porch. The church façade is recognizable by its asymmetrical design and contrasting colors and materials. Stone steps lead to the church entrance with a wooden door - the entrance is painted in a dark shade to contrast the yellowish façade. Wooden details like those on the door can also be found inside the church. The contrasting colors of the façade are reproduced in the church interior. The roof is divided into two zones; the central zone is elevated and provides clerestory lighting. The prominent central part of the roof breaks the austerity of the structure. There is a vestibule just inside the church entrance. The choir is supported by four thin rectangular pillars. The chancel rises three steps above the space for the faithful and ends in a straight wall. The strict lines of the floor plan are broken by the rounded lines of the baptistery, located to the left of the chancel, which is a departure from the rectangular plan. The pastoral center lies beyond the church chancel and is connected to it, but does not visually clash with it. The bell tower, built ten years after the church, stirred a great deal of public controversy. Its architect strived to reconcile tradition with contemporary building techniques and materials. The rectangular bell tower is separated from the church, emulating the Romanesque rectangular bell towers. Its contemporary style is evident from its form, which is reduced to a bare metal structure with no walls or ornaments. A large body of parishioners derided the design, and others still filed noise complaints due to its tolling. The very position of the church - alongside a major road - has been a contending issue, but there was simply a dearth of available land for a church in Trstenik.

\section{St. Mark's Parish in Neslanovac}

St. Mark's Parish in Neslanovac was founded in 1994, in the eastern part of the larger former Parish of the Blessed Virgin Mary, Mother of the Church, which was subsequently divided into three parts. The newly founded parish did not have a place of worship save for the small St. Domnius' Chapel in Dujmovača, which could not meet the needs of the parishioners. As a temporary solution, the Archdiocese set up three prefabricated aluminum buildings, which were donations from the Venice branch of Caritas (Vidović, 2004). Construction of the new parish church and the pastoral center began in 1996, based on the concept drawing by Maurizio Bergamo (Split-Makarska Archdiocese, 2016b). The architect Damir Rako designed the detail and working drawing (Vilogorac, 2005) (Figure 13).

St. Mark's Parish Church in Neslanovac has a square-in-octagon plan and covers $400 \mathrm{~m}^{2}$ (Vidović, 2004) (Figure 14). The roof construction stands out due to the octagonal shape emerging from the bulk of the church. It has four windows on each side and a pitched roof above, with a tall golden cross. Seeing as the church's bell tower is temporary, and 
quite some distance away from the church, the cross on top of the roof serves as a clear sign of the sacredness of the place. The façade features a roofed porch supported by six pillars. The church décor defers to post-conciliar instructions (Škunca, 1996); the disparity between this and the traditional places of worship is reflected in the centrally-placed altar

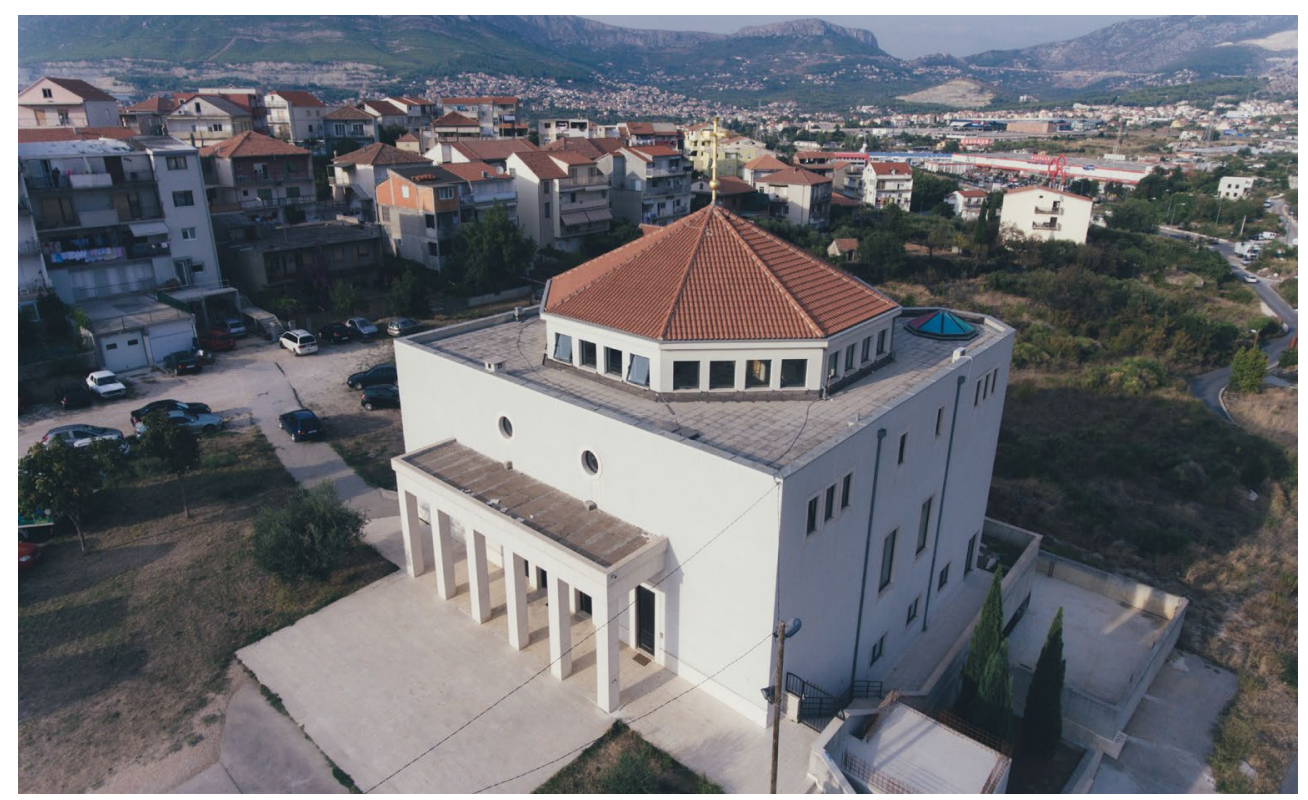

Figure 13. A roof view of St. Mark's Church. The pastoral center forms a coherent whole with the church and is located in the halls below it (Source: author's archive).

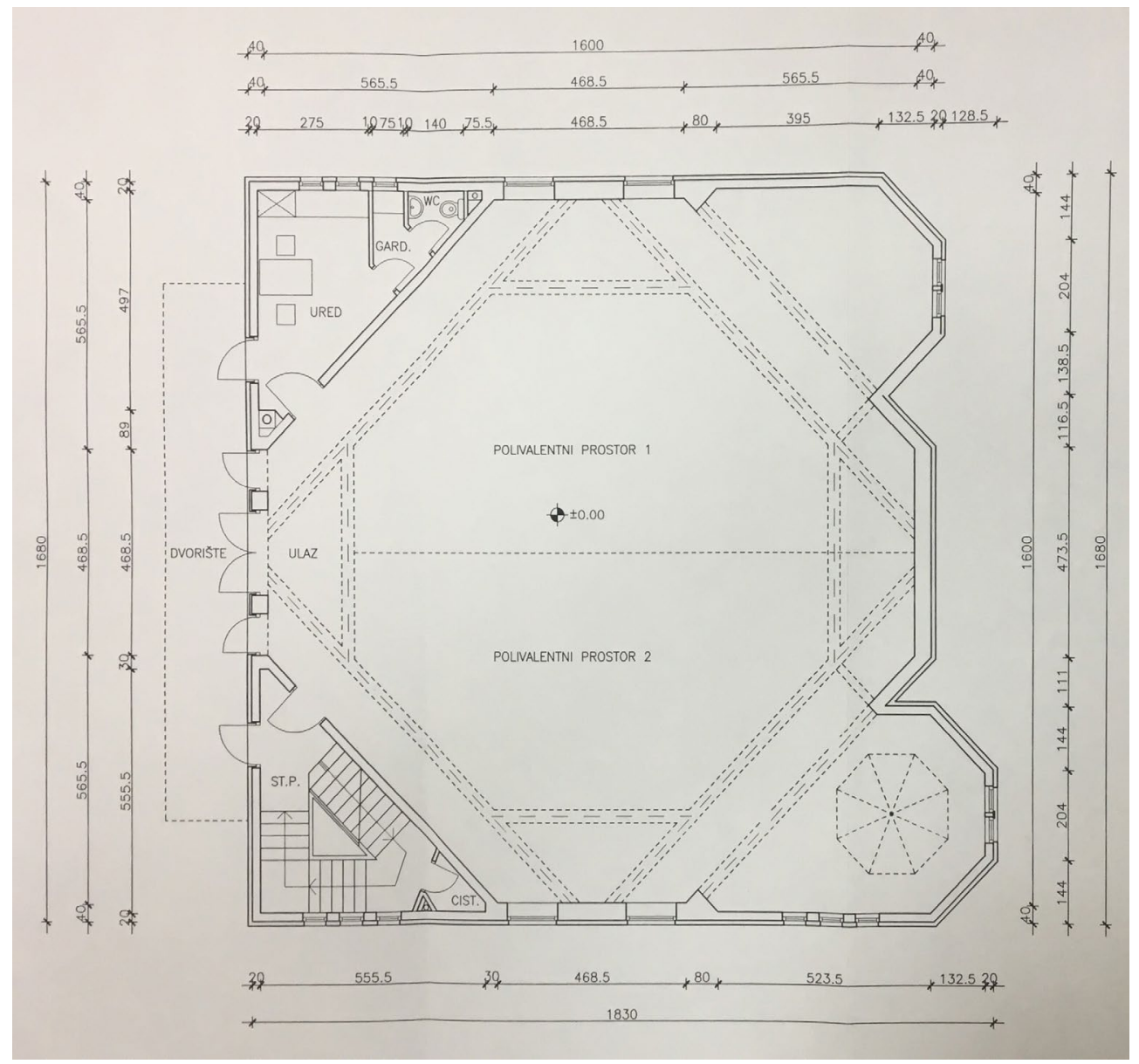

Figure 14. The floor plan of St. Mark's Parish Church in Neslanovac. The church has an octagon-in-square plan (SplitMakarska Archdiocese Archive, reproduced with permission). 
of St. Mark's Church, which would traditionally be placed in the chancel and raised above the rest of the church. The ambon is located above the altar, with the sedilia beyond that. The placement of pews is ambient. Sacraments are given in the empty central part of the church. The tabernacle stands in the right-side apse, overhung by a colorful octagonal glass roof to let in the light and illuminate the tabernacle. The pastoral center is located in the crypt. The entire sacral complex forms a coherent, harmonious whole. The interior of the church is embellished with large wall frescoes depicting the life of Christ.

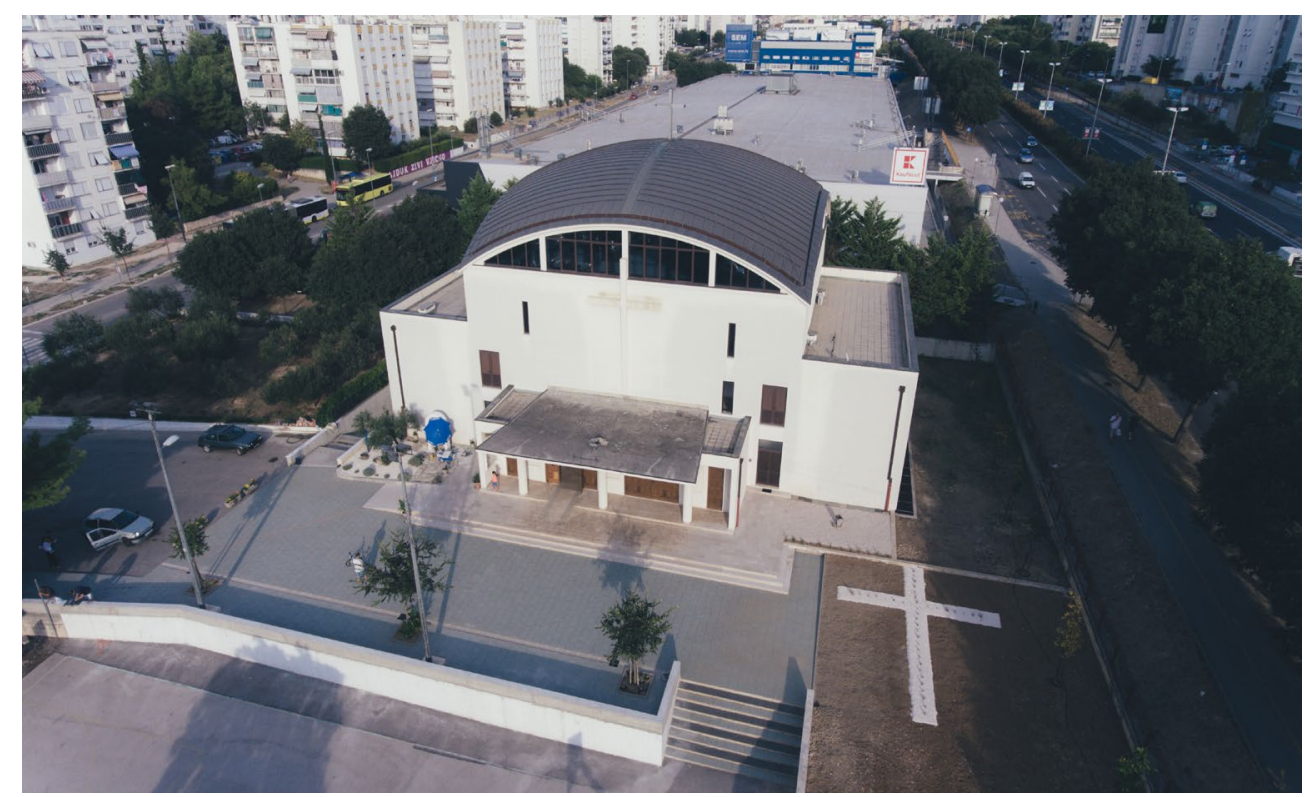

Figure 15. Church of St. Matthew the Apostle, aerial view. Pastoral halls lie to the left and right of the church, which towers above them (Source: author's archive).

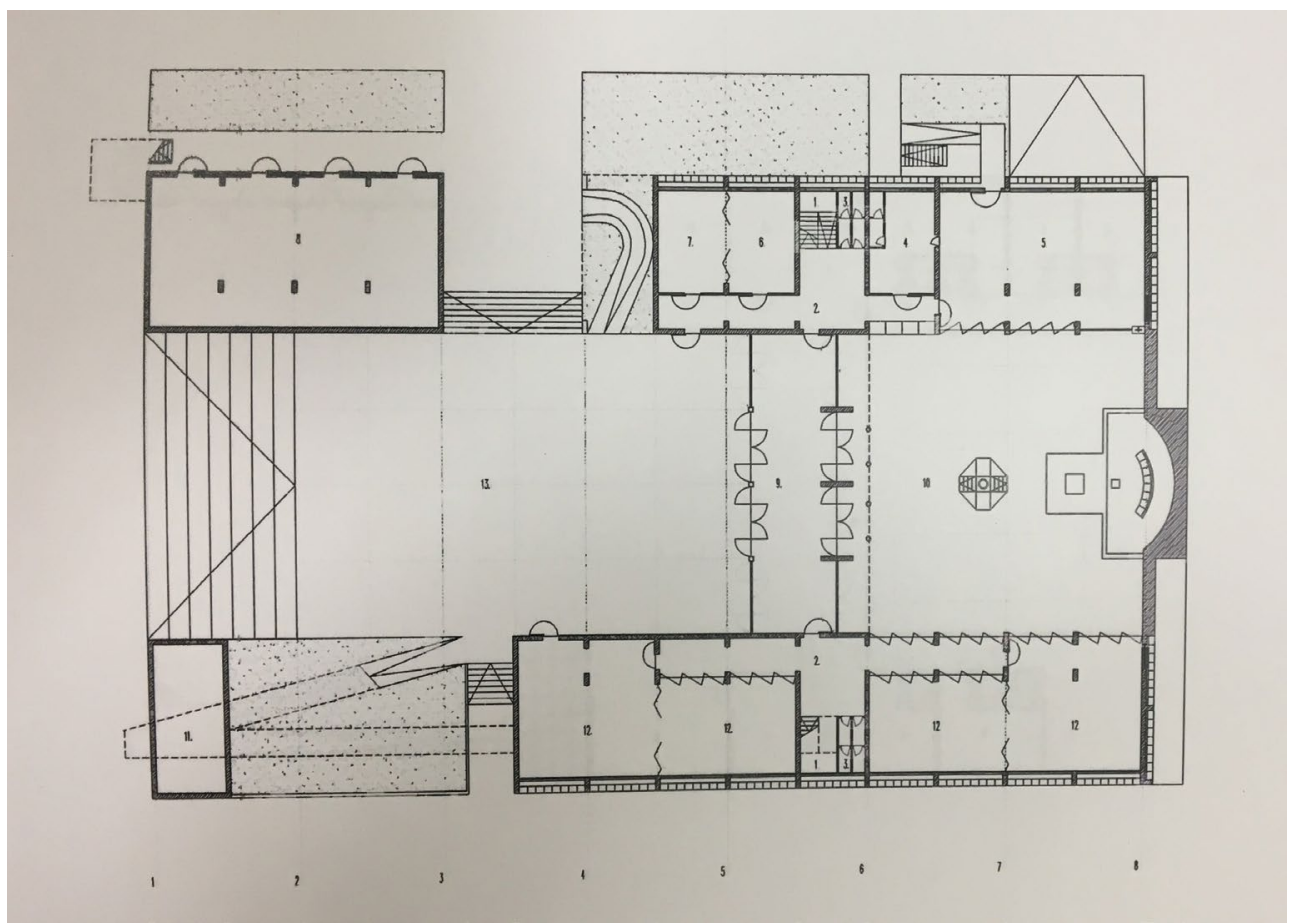

Figure 16. The concept floor plan for the Parish Church of St. Matthew the Apostle in Ravne Njive. The concept design also foresaw a bell tower, though this is yet to be built (Split-Makarska Archdiocese Archive, reproduced with permission). 


\section{Parish of St. Matthew the Apostle in Ravne Njive}

The Parish of St. Matthew the Apostle in Ravne Njive was founded in 1993, after its mother parish, the Blessed Virgin Mary, Mother of the Church in Brda (see Figure 2) was divided into three parts. Seeing as the new parish lacked sacral buildings, the pastor secured a temporary space in the basement of a residential building owned by the City. Construction of the new church began in 2000, based on drawings by the architect Ante Kuzmanić (Vidović, 2004) (Figure 15).

The church plan is rectangular (Figure 16). The concept drawing evidently envisioned a bell tower and various pastoral center halls, in addition to a liturgical chancel. The bell tower has not been built. The liturgical space covers $407 \mathrm{~m}^{2}$ (Vidović, 2004). The pastoral halls flank the church space, so the church appears like a three-nave building. The side rooms are walled off from the rest of the church and used for religious education classes. To the left of the chancel, there is a side chapel for liturgy on weekdays, built according to post-conciliar recommendations (Škunca, 1996). Two stories of wooden galleries that surround the main nave provide an additional space for parishioners. The church façade with three pillars and four doors is crowned with a roofed porch. The two main wooden doors lead to the vestibule or narthex, and the two smaller doors open to the premises of the pastoral center. There is a large stone cross above the front porch, extending to the dome of the church. This gives the church its recognizable look. As this type of rectangular-plan building does not commonly feature a rounded roof, this architectural solution comes as a surprise. It contributes to the contemporary look of the building and makes it recognizable. The windows of the church are in the roof zone, under the dome. The appearance of the façade is diminished by brown PVC doors, installed in the façade even on the second floor, although they serve no purpose there. The chancel is set into an internal apse, raised three steps above the rest of the church and furnished in stone. There is a large cross on the ceiling of the church. The second floor of the church holds the living quarters, and the space beneath the chancel is used for various religious gatherings. The church has its own parking lot and olive grove, and its orientation in relation to the roads in the settlement is favorable.

\section{Parish of St. Luke the Evangelist in Kocunar}

The Parish of St. Luke the Evangelist in Kocunar was founded in 1994. Since the parish lacked sacral buildings, the pastor repurposed the premises of what used to be private stores as a temporary parish chapel and celebrated liturgy there. Construction of the new Chapel of St. Luke the Evangelist began in 1996, based on the drawing by the architect Danko Colnago (Figure 17). The project has not been carried out in full, as a church was supposed to be built next to the chapel, and the chapel then turned into a pastoral center (Vidović, 2004).

The makeshift chapel has a rectangular floor plan, measuring $270 \mathrm{~m}^{2}$, and the planned area of the Church of St. Luke the Evangelist is about $350 \mathrm{~m}^{2}$ (Vidović, 2004) (Figure 18). In the concept design, the architect took a stance that, due to the high-rise buildings in the vicinity of the church, the symbolism and emphasis of the sacral space should not be broadcast by the bell tower, but rather by its "fifth façade”, i.e., the roof. More specifically, 


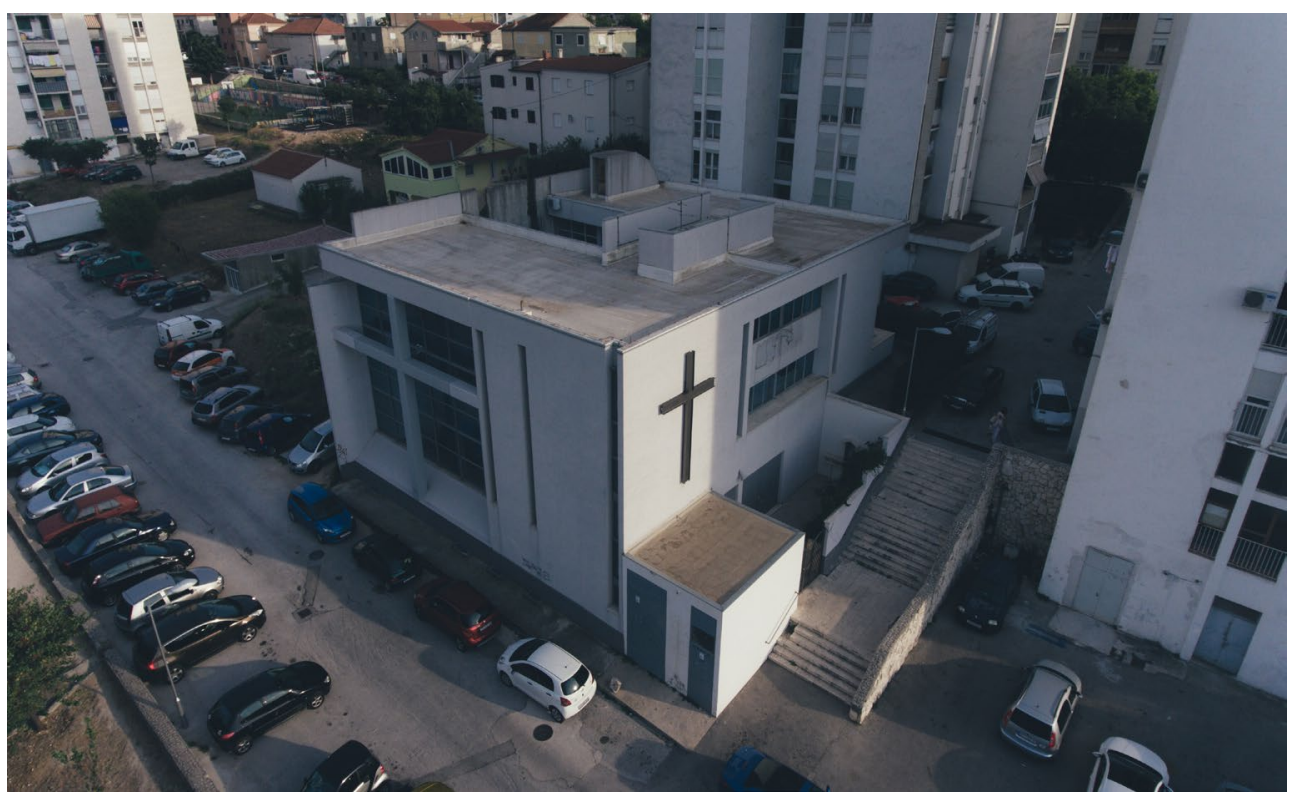

Figure 17. Aerial view of the built part of the Church of St. Luke the Evangelist (Source: author's archive).

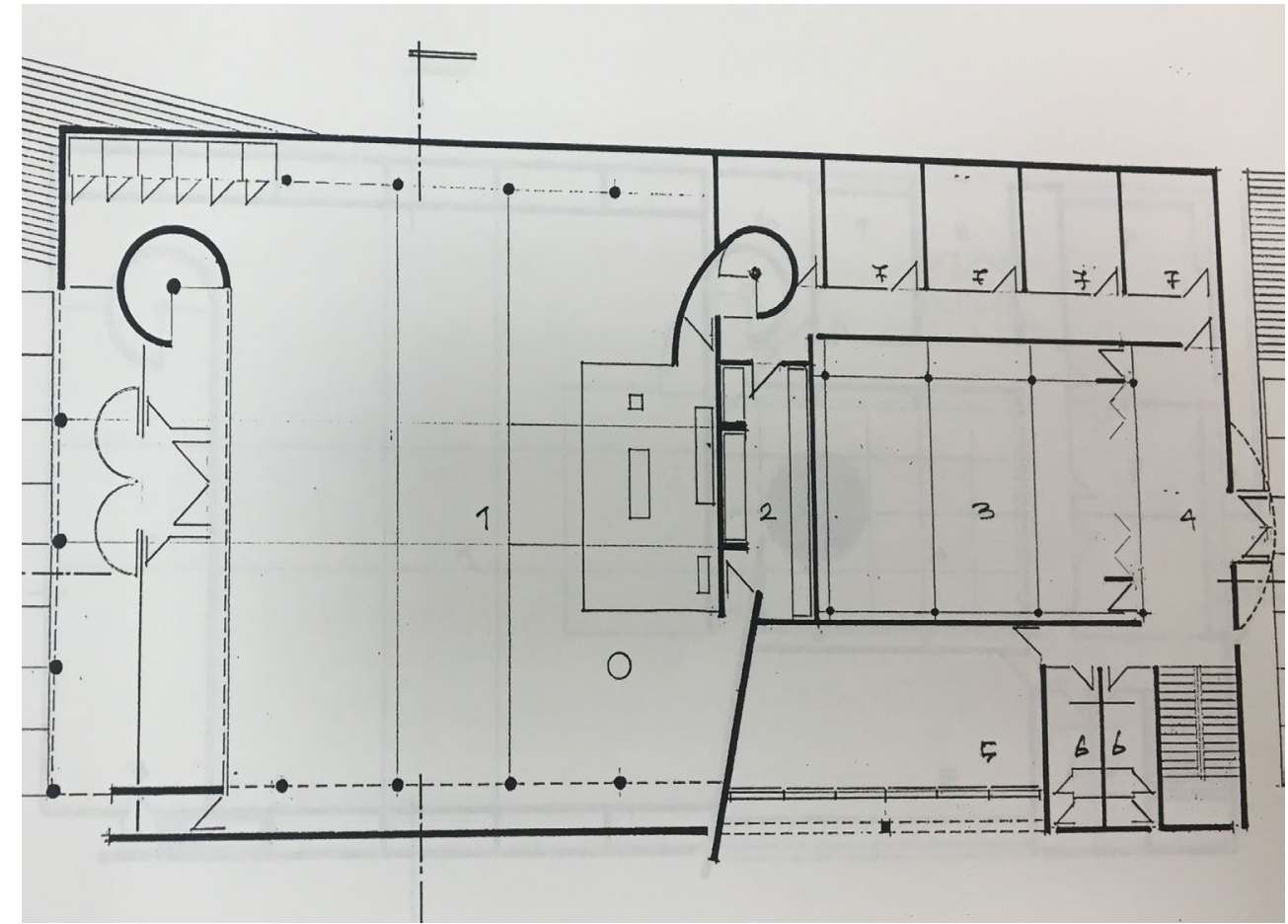

Figure 18. The floor plan of the Church of St. Luke the Evangelist in Kocunar (Split-Makarska Archdiocese Archive, reproduced with permission).

seeing as the church is surrounded by high-rises, the roof of the church is visible from the buildings. The architect cunningly devised a flat roof with a concrete cross, inset in waterproofing cobbles; however, seeing as the church has not been built, the roof is still just a concept. The bell gable was conceived as a steel structure, but it has also never been built. The only symbol of the sacredness of the Kocunar chapel is the iron cross on its façade. The north side of the chapel features large windows. The nave of the chapel is supported by four pillars on the left and on the right, and the chancel is raised by two steps, has a flat end, and features a wooden altar, ambon, and sedilia. To the left of the chancel, there is a small chapel of St. Luke separated by a wooden door, with its own altar, and to the right are the parish rooms. 


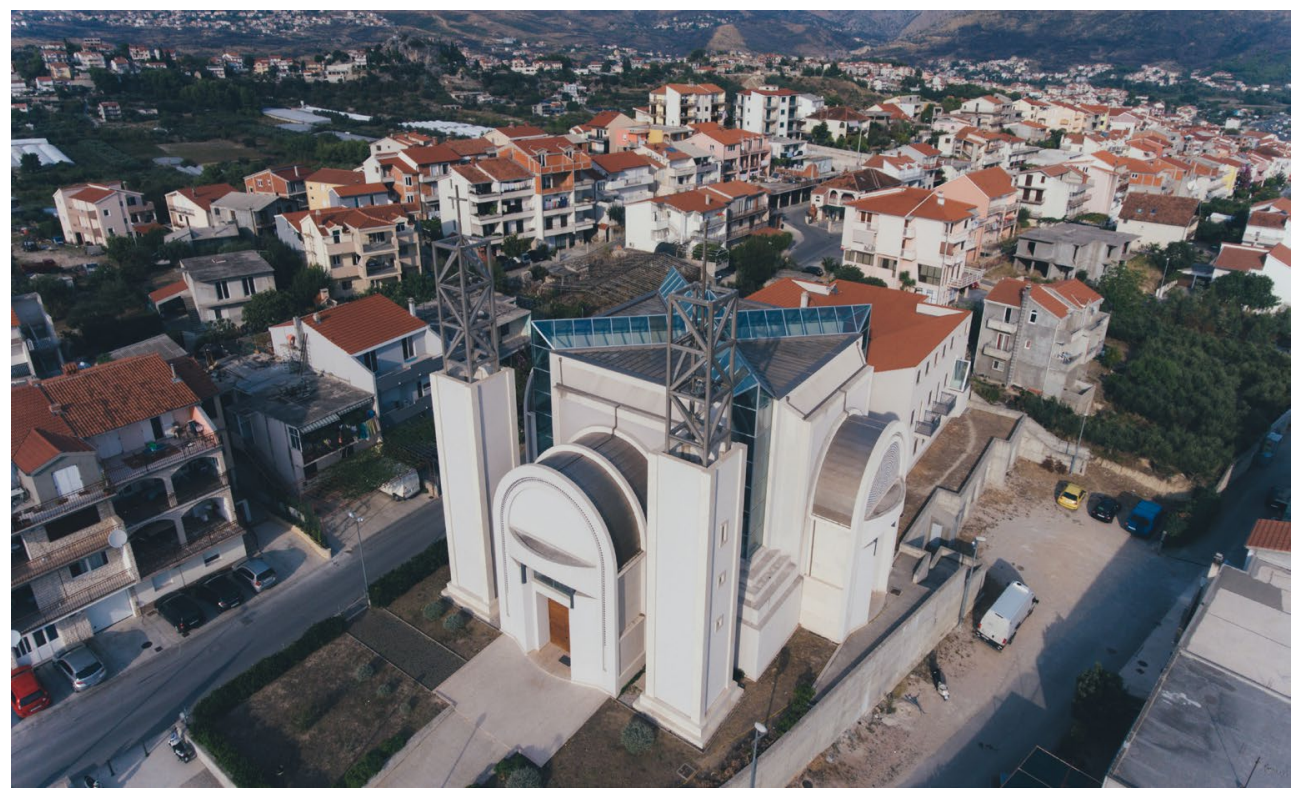

Figure 19. The Church of St. Leopold Bogdan Mandić, aerial view. The pastoral center lies beyond the church (Source: author's own archive).

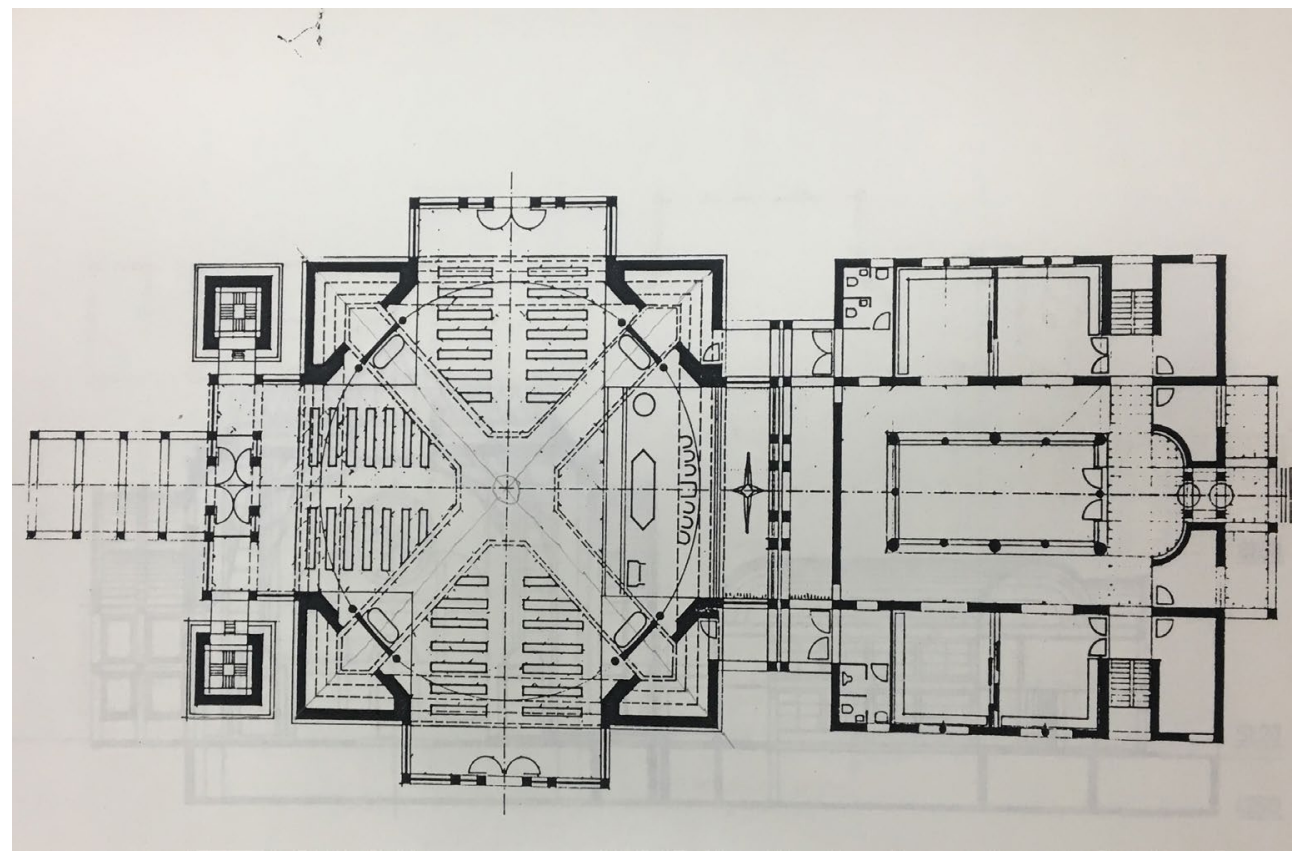

Figure 20. The floor plan of the Church of St. Leopold Mandić and the pastoral center. The floor plan is Greek-cross (SplitMakarska Archdiocese Archive, reproduced with permission).

\section{Parish of St. Leopold Bogdan Mandić}

The Parish of St. Leopold Bogdan Mandić was founded in 1989. The parish originally only contained the residence of the Carmelite Sisters of the Divine Heart of Jesus, which was later repurposed with minor upgrades into a temporary place of worship. The parish is located in the far eastern part of the city, in the settlement of Sirobuja (Figure 2). Construction of the parish church was began 1996, based on the drawings by Vjekoslav Ivanišević (SplitMakarska Archdiocese, 2016c) (Figure 19). 
The Church of St. Leopold Mandić in Sirobuja has a Greek-cross plan (Figure 20). The church covers about $500 \mathrm{~m}^{2}$ (Vidović, 2004). The four side chapels of the church hold a baptistery, a confessional, a tabernacle, and a statue of St. Leopold Bogdan Mandić, the titular of the parish church. They are separated from the rest of the interior by three semicircular arcades. Glass window openings extend from the side chapels toward the roof, following the arms that intersect in the shape of a cross. This roof design makes for an interesting play of light and shadow in the church. An additional pyramid roof was constructed above the intersection of the glass roof arms. The façade of this church is special due to its unique bell towers. They are located to the left and right of the entrance. They are closed from the foundation to the top. The ending of the bell towers is stripped to its metal structures that hold the bells and end in two crosses. The barrel-vaulted narthex also contributes to the unique shape of the façade, and this type of ceiling is repeated in all four façades. Contemporary spirit of this building is reflected in the choice of building materials: by combining stone, metal bell tower structures, the cladding of entryway arches, glass and wood, architect Ivanišević gave a new dimension to the sacral architecture of Split. Just behind the church entrance, there is a narthex with a choir supported by two pillars and a gallery that extends above the remaining two entryways. There are also two pairs of pillars on each side. The pastoral center lies beyond the church and is connected to it. The chancel faces east and is raised above the rest of the chancel. The altar, ambon, and tabernacle are made of a combination of wood and stone. A semicircular wall behind the sedilia is purely decorative, as is the hollow east façade with its cross. This architectural whole, together with the roof windows, is a key light accent that enlivens the church space and installs a sense of the sublime in the pious. With its appearance and monumentality, the church sticks out in the chaotic urban environment of Sirobuja (Figure 2) and makes no cohesive sense in the settlement. During the building of these new churches, architects had to deal with the challenging task of fitting them into the existing settlement, but urban engineers should have planned for future developments. St. Liborius' Church clearly shows that this has not always been easy or feasible, and sometimes it was impossible to meet all the criteria.

\section{Parish of the Sacred Heart of Jesus in Visoka}

The Parish of the Sacred Heart of Jesus was founded in 1966. The parish originally belonged to the Jesuits, but was later assigned to diocesan priests. The family house where the liturgy used to be held could not meet the needs of the parish. The site for the new church was finally found after a tender and various legal issues that followed. Construction of the new church began in 2004, based on the drawings by architect Dario Gabrić (Split-Makarska Archdiocese, 2016d) (Figure 21).

The floor plan of the Church of the Sacred Heart of Jesus in Visoka is a quarter-circle (Figure 22). The floor plan itself clearly broadcasts the architect's intent to turn to contemporary forms, as evinced by the entire building. The church has an area of $600 \mathrm{~m}^{2}$, and the premises of the pastoral center cover $500 \mathrm{~m}^{2}$ (Split-Makarska Archdiocese, 2016d). The façade of the church is a curved surface with a circular section above the wooden front door. The bell tower with a cross stands to the left of the west façade, separated from the church proper. Its volume and height obscure the pastoral center, so it forms a harmo- 


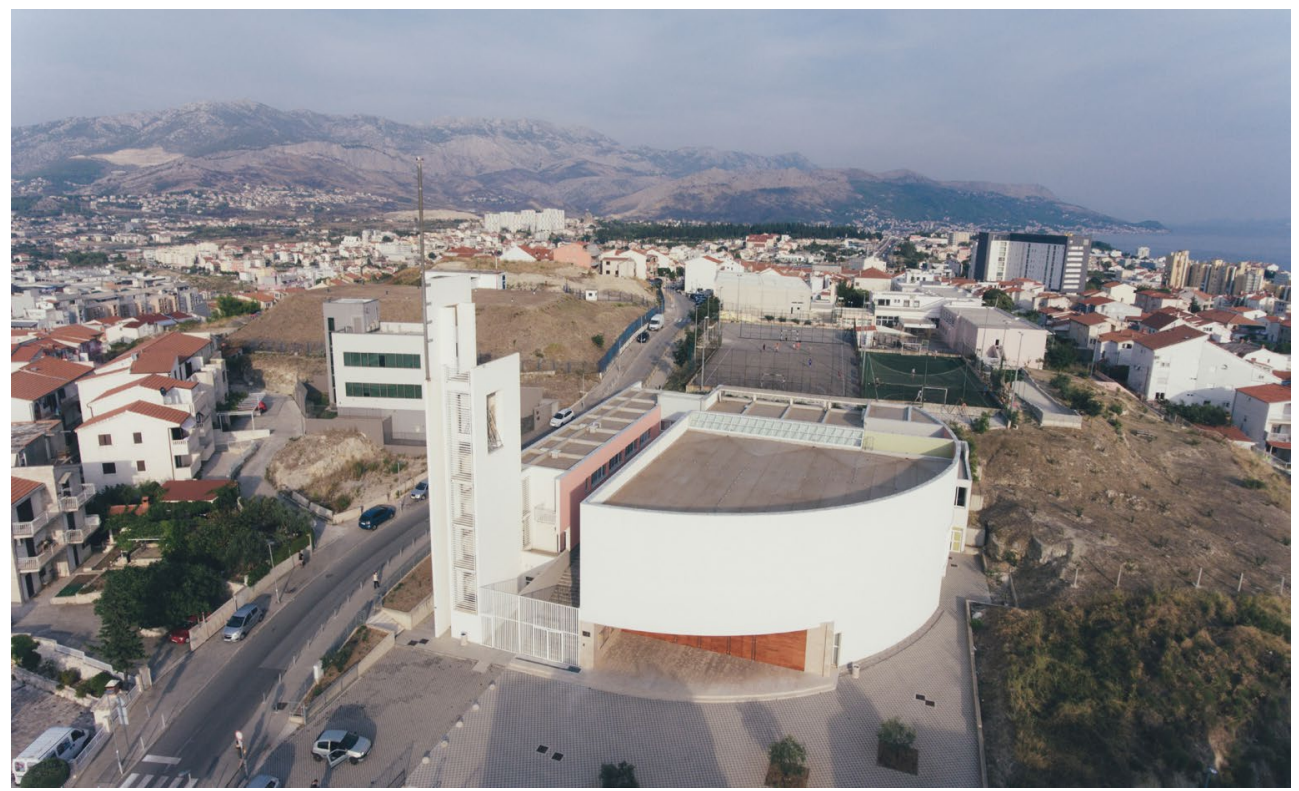

Figure 21. Aerial view of the front façade of the Church of the Sacred Heart of Jesus in Visoka. The pastoral center is located to the left of the entrance and is hidden by the bell tower (Source: author's archive).

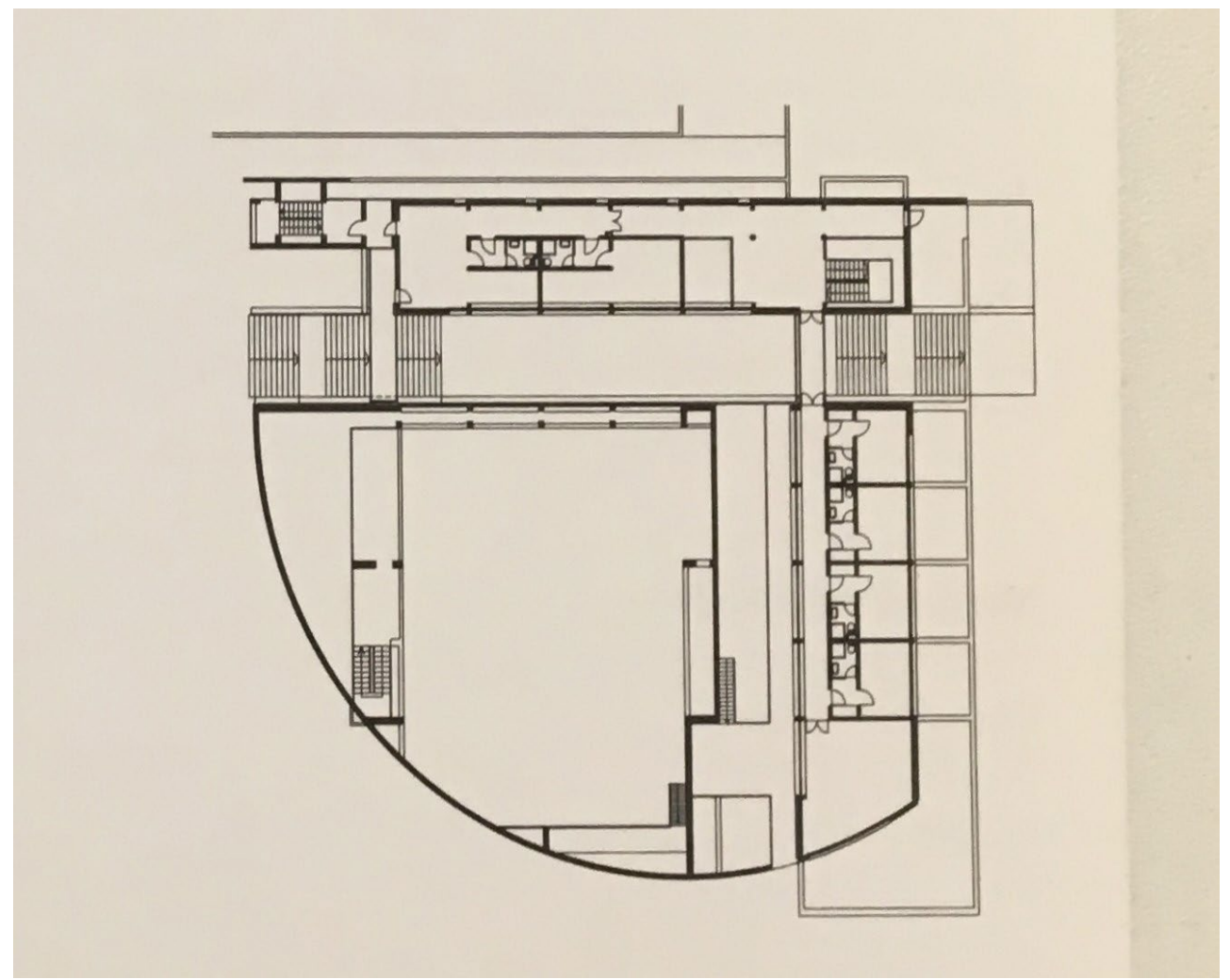

Figure 22. The floor plan of the Church of the Sacred Heart of Jesus in Visoka. The contemporary floor plan resembles a quarter circle (Bračot Matijević, 2011, p. 153, reproduced with permission).

nious whole with the façade of the church. The volume of the bell tower is broken up by mid-openings across its entire length. The six openings in the bell tower are covered by a metal lattice. The church is fenced off; in front of it there is a designated square, and the curving of the steps in front of the church entryway follows the church plan. The entryway features four wooden doors that lead to the narthex, and above it there is a choir. Right behind the entrance, there is a library, the legacy of the Jesuits. To the left, there is a chap- 
el that has only recently been walled off from the rest of the church with PVC openings, similar to the church in Ravne Njive (Figure 16). The side chapel - another post-conciliar recommendation adopted in this church - is used for mass on weekdays (Škunca 1996). The chancel is raised three steps above the nave and terminates in a straight wall, and the architect added a cross in the back wall of the chancel for decorative purposes. The large roof windows above the chancel provide a light accent that is crucial for the ambience of the church. The floor plan is contemporary, but does not comply with the post-conciliar instruction. This is in contrast with the contemporary rounded elliptical floor plan of the church in Žnjan (Figure 8). The Žnjan church also has curved pews, which further emphasize the centrality of the building. This layout and floor plan are in service of the reformed

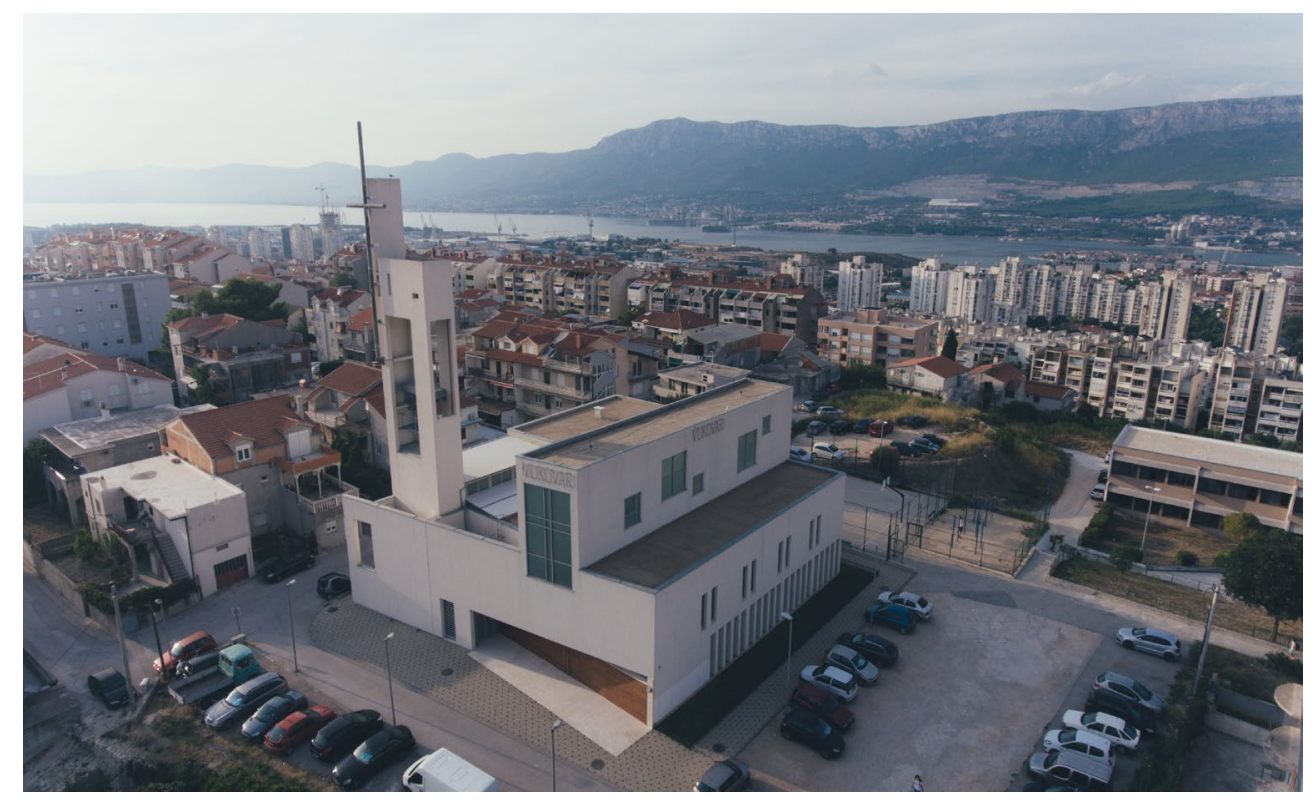

Figure 23. Aerial view of the front façade of the Church of St. Andrew the Apostle. The pastoral center lies to the left of the entrance, with a bell tower emerging from its body (Source: author's archive).

liturgy, with Christ as the Head and the Church as the body that actively participates in worship; however, in the Church of the Sacred Heart of Jesus in Visoka, this altar-focused communal element is lacking.

\section{St. Andrew's Parish in Sućidar}

St. Andrew's Parish in Sućidar was founded in 1991. The parish lacked an adequate place for worship, so the fallout shelter of an elementary school was used as a makeshift solution. Construction of the new church on top of Sućidar began in 2009, based on the drawings by Dario Gabrić (Split-Makarska Archdiocese, 2016e) (Figure 23).

St. Andrew the Apostle in Sućidar is a single-nave church with a trapezoidal floor plan (Figure 24). The church covers an area of $390 \mathrm{~m}^{2}$, with the pastoral center on its left (SplitMakarska Archdiocese, 2016e). The church lacks a square or any adequately fenced off space, and the entry to the parking lot passes right in front of the main entrance of the church. The façade is interesting because the main wooden door does not follow the horizontal line of the wall and instead slants into the body of the church. Above the entrance 


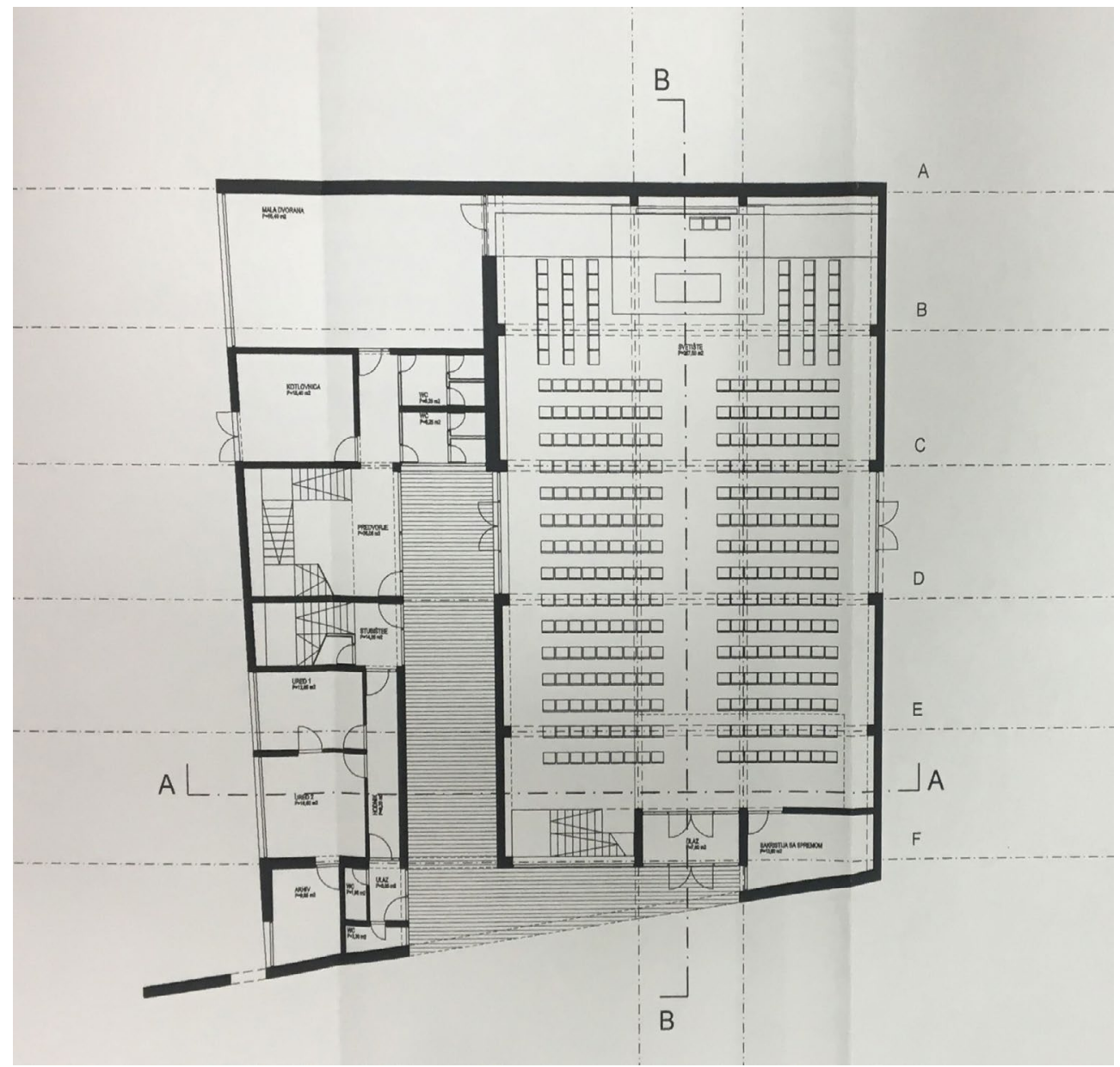

Figure 24. The concept floor plan of the Church of St. Andrew the Apostle in Sućidar with its pastoral center. The church has a trapezoidal floor plan (Split-Makarska Archdiocese Archive, reproduced with permission).

there is a rectangular opening that is part of the raised roof zone. The central part of the roof provides clerestory lighting as it contains large square windows, and there are narrow rectangular stained-glass windows in the lower zone of the church, along its entire length. A rectangular bell tower stands to the left of the façade, emerging from the body of the pastoral center. The rectangular panels cut into the bell tower show its metal structure and bells. It also features a large cross, attached to the body of the bell tower with its largest surface, so only the upper end protrudes on top. The façade features a roofed porch, leading to the narthex through a wooden door. A sacristy sits to the right of the entryway. The church interior features a network of pylons extending to the ceiling. The interior of the church is simple, with an emphasis on stained glass windows depicting the Stations of the Cross and an altar mosaic by Josip Botteri Dini (Vidović, 2004). The chancel is raised by three steps and ends in a flat wall; the altar and ambon are made of stone.

\section{Parish of the Motherhood of the Blessed Virgin Mary in Brda}

Parish of the Motherhood of the Blessed Virgin Mary was founded in 1966. After its founding, mass was originally held in St. Domnius' Chapel in Dujmovača. A building with a liturgical space on the first floor and a parish house on the second were erected later. The first design for the parish church in Brda was created by the Venetian architect Maurizio Bergamo, but the project was not carried out due to various proprietary issues involving 


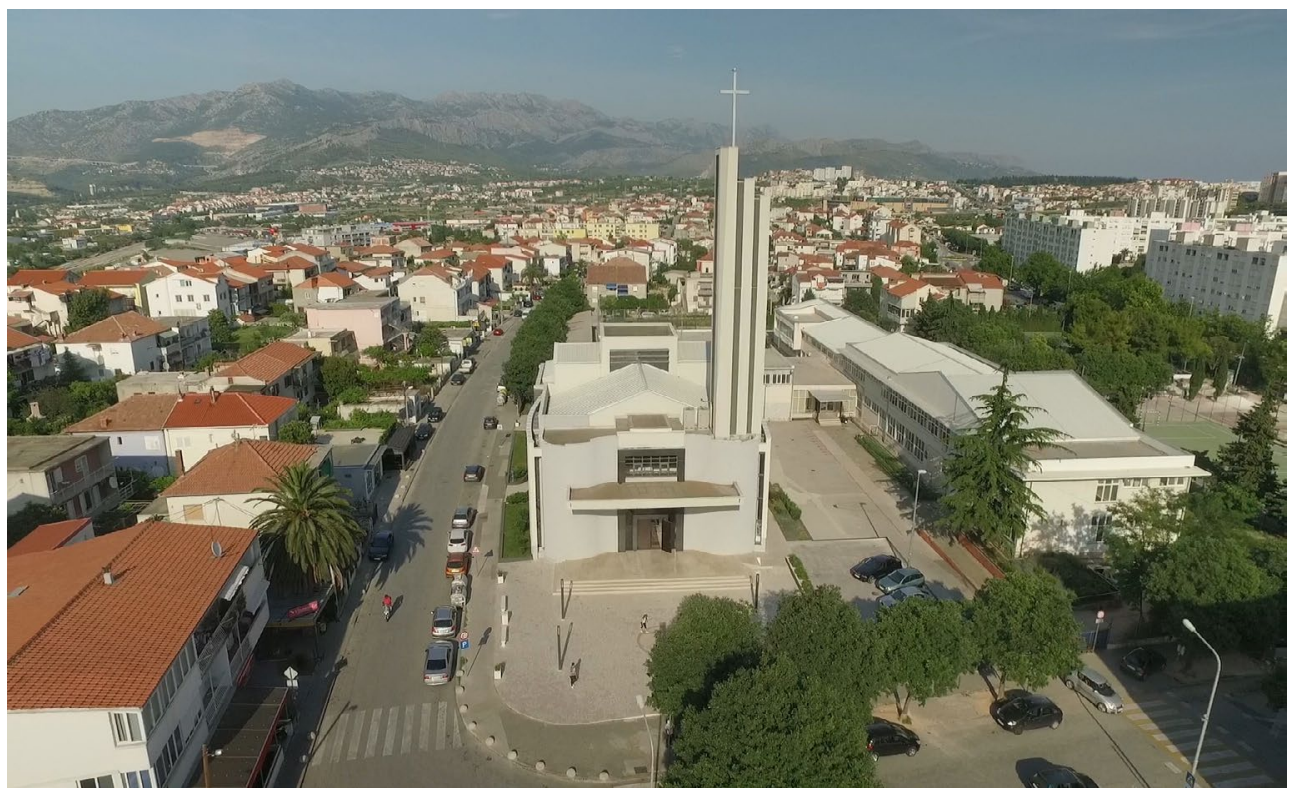

Figure 25. Aerial view of the Church of the Motherhood of the Blessed Virgin Mary. The pastoral center lies beyond the church (Source: author’s archive).

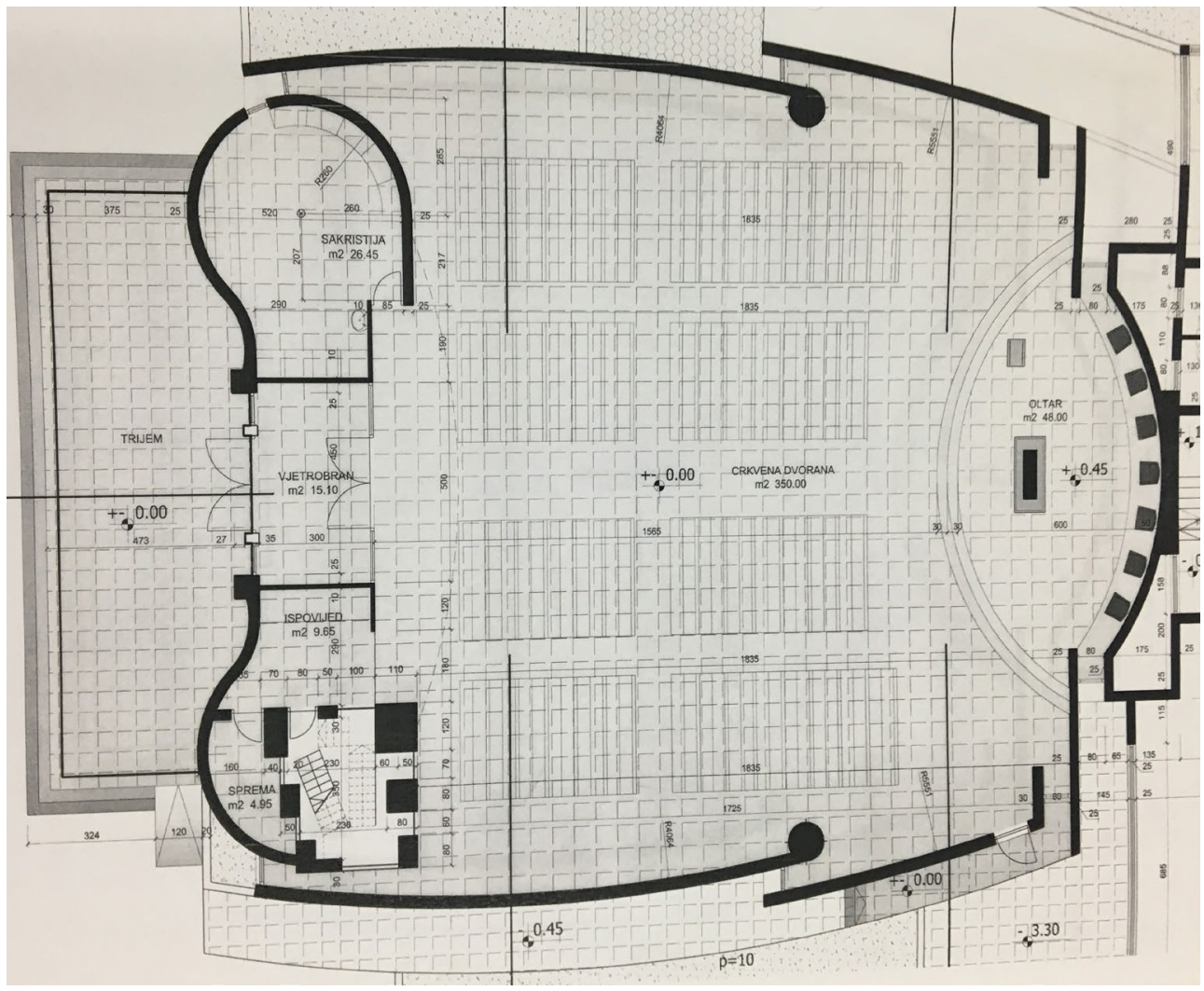

Figure 26. The floor plan of the Church of the Motherhood of the Blessed Virgin Mary in Brda. The floor plan is rounded, with distinctive half-cylinder façade walls (Archive of the Parish of the Motherhood of the Blessed Virgin Mary in Brda, reproduced with permission).

the construction site (Vidović, 2004). The new site sits in the very center of the neighborhood, on the property of its elementary school. Construction of the new church began in 2011, based on the drawings by the architect Zoran Jeramaz (Tušek, 2015) (Figure 25).

The floor plan of the Church of the Motherhood of the Blessed Virgin Mary is rounded, covering the area of $530.50 \mathrm{~m}^{2}$ (Figure 26). The roundness of its form is reflected in the 
curved half-cylinder front walls as well as north and south façades, which taper toward the apse of the chancel in the east. The cobbled square in front of the church separates the sacral space from the main intersection in the settlement. The decorative stone cross design in the cobblestone of the square serves to announce the sacredness of the space above the steps. The bell tower is connected to the church proper. A staircase leading to the choir is located in the bell tower. The curved walls draw attention to the façade, which is recognizable by the tinted metallized glass and the console above the entryway, offsetting the whiteness of the façade. Beyond the entryway, there is a narthex, separated from the nave by a glass door. The chancel rises three semicircular steps above the nave. The semicircular chancel comprises a stone ambon and altar, as well as wooden pews for the priests. An altar mosaic by Father Marko Rupnik has also been planned, but the project has not yet been carried out. To the right of the altar, there is a stone baptistery, and to the left, there is a stone pedestal for a golden tabernacle. The pastoral center lies behind the church, without disturbing the aesthetic of its façade. Many of the residents were against church location, claiming that the Church took away last free location suitable for children playground. However, the Brda district (Figure 2) features a greater diversity of facilities for children than many other neighborhoods in Split. The location of the church is admittedly not ideal, but a more suitable site was unavailable.

\section{Discussion}

Following the independence of the Republic of Croatia after its break with Yugoslavia (Perković Paloš, 2020), the data analysis conducted by the Split-Makarska Archdiocese found that older parishes had to wait twice as long for the consecration of their churches. More specifically, these have been founded during the socialist regime (1966-1994), which not only saw sacral building as not a priority but also as undesirable in the Split city area. However, even some younger parishes had to wait over ten years on average for the consecration of the parish church, due to issues with obtaining building location permits and an array of proprietary issues. Location played a key role in the design and final appearance of the churches. Thus, in 1993, the Split-Makarska Archdiocese adopted a plan to build twelve new parish churches with their respective pastoral centers (Table 1). Eastern Split was expanding rapidly, and the Archdiocese could not provide adequate answers to cater to the needs of the pious.

As the neighborhoods were already quite formed when the search for new church sites began, the architects were faced with a challenging task. They needed to integrate these sacral buildings into already developed settlements and tie them into a cohesive whole, all the while preserving visible and clear signs of their holiness. Depending on the site, the architects strove to leave space for a square in front of the churches to symbolically and spatially distance these sacral buildings from their surroundings and signal that one is about to step into a holy space. The church in Brda (Figure 25) is an example of a church located in the center of the neighborhood, but its architect solved this problem by opening a large square in front of the church's entryway. The square sets the church space apart from secular facilities and features a cross set into the cobblestone, which clearly communicates that one is not standing in just any square, but a parish square. 
Table 1. Summary of the key characteristics of 12 parish churches built in city of Split since 1990

\begin{tabular}{|c|c|c|c|c|c|c|}
\hline Church (City district) & $\begin{array}{l}\text { Year of } \\
\text { founda- } \\
\text { tion of the } \\
\text { parish }\end{array}$ & $\begin{array}{l}\text { Beginning } \\
\text { of con- } \\
\text { struction }\end{array}$ & $\begin{array}{l}\text { Ground floor } \\
\text { shape }\end{array}$ & $\begin{array}{c}\text { Space } \\
\left(m^{2}\right)\end{array}$ & Architects & $\begin{array}{c}\text { Figure } \\
\text { in the } \\
\text { text }\end{array}$ \\
\hline St. Paul the Apostle (Pujanke) & 1980. & 1993. & $\begin{array}{l}\text { Greek-cross- } \\
\text { in-octagon }\end{array}$ & 600 & Ante Lijić, Tihomir Liović & 3 \\
\hline St. Joseph's (Mertojak) & 1990. & 1996. & irregular & 400 & Neno Kezić, Eugen Širola & 5 \\
\hline Church of Our Lady of Mercy (Žnjan) & 1966. & 1996. & $\begin{array}{l}\text { rounded } \\
\text { elliptical }\end{array}$ & 380 & Marijan Hržić & 7 \\
\hline St. Liborius (Mejaši) & 1975. & 1994. & quatrefoil & 700 & Slaven Rožić & 9 \\
\hline St. John the Baptist (Trstenik) & 1991. & 1996. & rectangular & 380 & Jerko Rošin, Robert Plejić & 11 \\
\hline St. Mark (Neslanovac) & 1994. & 2000. & $\begin{array}{l}\text { square-in- } \\
\text { octagon }\end{array}$ & 375 & Damir Rako & 13 \\
\hline St. Matthew the Apostle (Ravne Njive) & 1993. & 2000. & rectangular & 400 & Ante Kuzmanić & 15 \\
\hline St. Luke the Evan-gelist (Kocunar) & 1994. & 1996. & rectangular & 270 & Danko Colnago & 17 \\
\hline St. Leopold Bog-dan Mandić (Sirobuja) & 1989. & 1996. & Greek-cross & 500 & Vjekoslav Ivanišević & 19 \\
\hline Sacred Heart of Jesus (Visoka) & 1966. & 2004. & $\begin{array}{l}\text { quarter- } \\
\text { circle }\end{array}$ & 600 & Darijo Gabrić & 21 \\
\hline St. Andrew (Sućidar) & 1991. & 2009. & trapezoidal & 390 & Darijo Gabrić & 23 \\
\hline $\begin{array}{l}\text { Motherhood of the Blessed Virgin } \\
\text { Mary (Brda) }\end{array}$ & 1966. & 2011. & rounded & 500 & Zoran Jeramaz & 25 \\
\hline $\begin{array}{l}\text { Motherhood of the Blessed Virgin } \\
\text { Mary (Brda) }\end{array}$ & 1966. & 2011. & rounded & 500 & Zoran Jeramaz & 25 \\
\hline
\end{tabular}

The bell tower is another architectural feature with the ability to symbolically raise a contemporary church above the surrounding buildings. The bell towers of the new Split churches do not hold the same symbolic power and value for the city aesthetic as their counterparts of yore. Still, some architects strove to maintain ties with the tradition, but with a contemporary twist. For example, Hržić enhanced the Žnjan church with a bell gable (Figure 7); Kezić and Širola fashioned their bell tower after the Renaissance archetype (Figure 5), but juxtaposed it with the highly irregular contemporary church plan; in Trstenik, Rošin and Plejić (Figure 11) renovate the Romanesque bell tower by reducing it to a bare metal frame; and Ivanišević employed the "unfinished" model for his innovative bell tower of the church in Sirobuja (Figure 19).

The dimensions of these churches are optimal; the rationalization principle was implemented partly due to the fact that they were built on the only available sites, as well as due to the financial circumstances of the parish and the parish community.

The average area of the parish church thus ended up being about 400 square meters. Looking at the floor plan, 3 out of these 12 churches have a rectangular plan - namely; the one in Kocunar (Figure 18), Ravne Njive (Figure 16), Trstenik (Figure 12). The church in Brda (Figure 26) has rounded floor plan, while Sućidar (Figure 24) has a trapezoidal. The church in Mejaši (Figure 10), with its Greek cross plan reminiscent of early Christian basilicas, is the largest. Pujanke (Figure 6), Neslanovac (Figure 14), and Sirobuja (Figure 20) have an octagon-in-square plan and are centrally oriented. Žnjan (Figure 8) is also centrally oriented, with a rounded elliptical floor plan, and Mertojak (Figure 6) and Visoka (Figure 22) have unusual floor plans (irregular ark and quarter-circle). The floor plan largely affects the manner of celebrating liturgy. The Second Vatican Council reformed the liturgy and issued building recommendations to enable active participation of the pious, 
as well as make them feel the communion with Christ at its center. Throughout history, churches have had a strong longitudinal axis with side altars, but contemporary sacral architecture has gradually abandoned such solutions. The interior decor of Split churches is very modest. The building material is mostly a combination of reinforced concrete and stone. The façade ornaments are usually made of marble. The workmanship is quite poor, as many churches are fighting a losing battle with leaks, moisture, cracked walls, and dilapidated façades. It should be borne in mind that these churches are only twenty or so years old.

\section{Conclusion}

If we were to consider all the parameters described above, it would be difficult to single out a Split church with the best architectural solution; evaluating the architectural and urban design solutions may in any case reveal a contemporary model for sacral building. Contemporary sacral buildings should be placed in a tranquil environment, such as in the case of Žnjan (Figure 7). The church square may be designed as a park, as some resent the Church for appropriating green spaces in neighborhoods. It would be wise to place the pastoral center behind the church, as is the case in Mertojak (Figure 5), so it does not take away from the aesthetic of the façade; alternatively, the pastoral center may form a unified whole with the building, as is the case in Neslanovac (Figure 13). It would be desirable to harmoniously balance the bell tower with the architecture of the rest of the church, as in Žnjan (Figure 7) or Brda (Figure 25). Contemporary churches would do well to make away with the elongated longitudinal axis and make space for the post-conciliar renewal of the liturgy by directing the faithful toward the altar, so they may actively participate in the liturgy and communion with Christ. Contemporary sacral architecture would do well to keep in touch with tradition, but also take a step forward in keeping up with the times.

Provenance: Submitted. This manuscript is based on the master's thesis by Gabrijela Matić, deposited in the Dabar repository (https://urn.nsk.hr/urn:nbn:hr:172:314322).

Peer review: Externally peer reviewed.

Received: 18 January 2021 / Accepted: 20 April 2021 / Published online: 13 July 2021.

Acknowledgements: Special thanks to Split-Makarska Archdiocese for allowing the publication of photos from the archives. We are very grateful to pastors dn Darko Matijević (Parish of the Motherhood of the Blessed Virgin Mary in Brda) and dn Anđelko Dukić (St. Liborius' Parish) for allowing us the publication of photos from parish archives

Funding: This research received no specific grant from any funding agency in public, commercial or not-for-profit sectors.

Authorship declaration: Both authors planned and designed research. GM collected all the data and literature, analyzed and interpreted the data and wrote and edited the manuscript. ŽP analyzed the data and edited the manuscript. Both authors participated in the revisions of the manuscript.

Competing interests: The authors completed the ICMJE Unified Competing Interest form (available upon request from the corresponding author), and declare no conflicts of interest. 


\section{ORCID}

\section{References}

Bračot Matijević, S. (2005). Crkva Presvetog Srca Isusova na Visokoj. In D. Tušek (ed.) Split Arhitektura 20. stoljeća Vodič (pp. 104). Split: University of Split, Faculty of Civil Engineering and Architecture

Duplančić, A. (2011). O splitskim zvonicima. Kulturna baština, (37), 143-172. Retrived from https:// hrcak.srce.hr/90025.

Klempić, S. (2004). Razvoj stambenih naselja Splita nakon Drugog svjetskog rata. Croatian Geographical Bulletin, 66 (2), 95-119. Retrieved from https://hrcak.srce.hr/17620.

Mumford, L. (1968). The City in History: Its Origins, Its Transformations, and Its Prospects. Zagreb, Naprijed.

Perković Paloš, A. (2020). The Croatian War of Independence. In: M. Marušić (Ed.), Croatia: Past Present and Future Perspectives (pp. 267-294). Nova Science Publishers.

Second Vatican Council. (2008). Documents. Zagreb, Kršćanska sadašnjost.

Split-Makarska Archdiocese (2016a). Župa sv. Liberana - Mejaši. Retrieved from https://smn.hr/splitmejasi.

Split-Makarska Archdiocese (2016b). Župa sv. Marka Evanđelista - Neslanovac. Retrieved from https://smn.hr/split-neslanovac.

Split-Makarska Archdiocese (2016c). Župa sv. Leopolda Bogdana Mandića - Sirobuja. Retrieved from https://smn.hr/split-sirobuja.

Split-Makarska Archdiocese (2016d). Župa Presv. Srca Isusova - Visoka. Retrieved from https://smn. hr/split-visoka.

Split-Makarska Archdiocese (2016e). Župa sv. Andrije apostola - Sućidar. Retrieved from https://smn. $\mathrm{hr} /$ split-sucidar.

Škunca, B. (1996). Temeljne odrednice za teologiju bogoslužnog prostora. In B. Škunca (Ed.), Bogoslužni prostor - crkva - u svjetlu teologije, arhitekture i umjetnosti: zbornik Savjetovanja za upravitelje crkava, arhitekte i umjetnike, Split, October 17 and 18, 1995. Zadar: Croatian Institute of Liturgical Pastoral.

Tušek, D. (1996). Arhitektonski natječaji u Splitu 1945. - 1995. Split, Split Society of Architects, Faculty of Civil Engineering in Split.

Tušek, D. (2015). Arhitektonski natječaji u Splitu 2006. - 2010. Split: University of Split, Faculty of Civil Engineering, Architecture and Geodesy and the Split Society of Architects.

Vidović, M. (2004). Splitsko-makarska Nadbiskupija: župe i ustanove. Split. Splitsko-Makarska Nadbiskupija.

Vilogorac, I. (2005). Splitske crkve: spomenička baština. Split. Ex libris.

Vlaić, I. (2005). Church of Our Lady of Mercy in Žnjan. In D. Tušek (ed.) Split Arhitektura 20. stoljeća Vodič (pp. 104). Split: University of Split, Faculty of Civil Engineering and Architecture. 